\title{
STUDIES ON SOME SPECIES OF CULEX (MELANOCONION), WITH THE DESCRIPTION OF A NEW ONE FROM SOUTHERN BRAZIL (DIPTERA: CULICIDAE) *
}

\author{
Oswaldo Paulo Forattini * *
}

Maria Anice Mureb Sallum **

\begin{abstract}
FORATTINI, O.P. \& SALLUM, M.A.M. Studies on some species of Culex (Melanoconion), with the description of a new one from Southern Brazil (Diptera: Culicidae). Rev. Saúde públ., S. Paulo, 21: $123-56,1987$.
\end{abstract}

ABSTRACT: Redescription of Culex (Melanoconion) oedipus Root and of Cx. (Mel.) plectoporpe Root, as well as the description of a new one, named $C x$. (Mel.) rabelloi, are made. The material was collected in S.Paulo State, Southern Brazil. The descriptions include adults, pupal and larval stages, illustrating the morphological aspects and with pictures of breeding places. Some data about known distribution and bionomics are presented, remarking that all the three species seem to be closely associated with artificial manmade enviroments.

UNITERMS: Culex (Melanoconion) oedipus. Culex (Melanoconion) plectoporpe. Culex (Melanoconion) rabelloi. Culex (Melanoconion) phlogistus. Culex (Melanoconion) albinensis. Insect vectors. Ecology, vectors.

\section{INTRODUCTION}

In the sequence of studies on mosquitoes of the Ribeira Valley and of other regions of S.Paulo State, Brazil, several species of Culex (Melanoconion) were being remarkably obtained by the collections made. Among these were identified Culex oedipus Root and $C x$. plectoporpe Root as well as another, hitherto considered as Culex albinensis Bonne -Wepster and Bonne, as a conseqence of more detailed studies proved to be really an undescribed species.

Very few data are available for a better knowledge of these species. From the bionomic point of view all three showed a well-marked preference for association with artificial manmade environments, showing this a significant adaptation capacity and so a good level of ecological valency. Therefore, we take this opportunity to fully redescribe $C x$. oedipus and $C x$. plectoporpe, and also to describe and name the new species.

For the descriptions the terminology utilized was that of Harbach and Knight (1980), and the general outline followed those of Harbach and col. (1984). As only larval exuviae were available, the descriptions were represented by semi-schematics drawings of these stages.

\section{Culex (Melanoconion) oedipus Root}

Culex (Choeroporpa) oedipus Root, 1927: 588 (male). Type-locality: Magé, Sant'Anna, Rio de Janeiro, Brazil.

Culex (Melanoconion) oedipus of Rozeboom and Komp, 1950: 94 (resurrected from synonymy with phlogistus); Lane, 1953: 446; Duret, 1954: 117 (1 male, Ciervo Petizo, Presidente Perón
[Chaco], Argentina); Garcia and Casal, 1965: 9 (1 male, Canal 6 y Paraná de las Palmas, Argentina); Sirivanakarn and Jakob, 1981: 198 (1 male, San Justo, Santa Fé, Argentina).

Adult. - A small dark brownish species.

FEMALE. - Body dark almost entirely clothed by mainly dark scales. Head. - Antenna dark, mean length $1.64 \mathrm{~mm}$; flagellum whorls with 6 setae. Proboscis completely covered by dark scales, length $1.4-1.6 \mathrm{~mm}$, mean $1.5 \mathrm{~mm}$. Maxillary palpus entirely dark, length $0.2-0.3 \mathrm{~mm}$, mean $0.25 \mathrm{~mm}$, about 0.2 of the proboscis length. Vertex (Fig. 2F, male) with grayish appressed spatulate scales on dorsum, paler scales laterally, forked scales dark, with few falcate whitish ones along occipital region; ocular and interocular setae lengthy dark, lightly golden sheen. Cibarial armature. (Fig. 2A, B and Fig. 4CA, Ct). - Gutther-shaped, dorsal surface pronouncedly arched. Cibarial bar developed, large, 0.75 distal quitinized, 0.25 proximal hyaline, strongly concave, with about $10-12$ cibarial teeth with sizes gradually smaller in lateral direction where they became visible on lateral profile even though something deformed by the usual prepara. tion techniques for common microscopy; cibarial teeth fold shaped like pan tiles, borne on transverse bar, anteriorly bearing large spatulate hyaline rod posteriorly serrated along margin that bears lateral small thom-shaped prominences one at each side, dorsally each connected by transversal bridges; dorsal surface of cibarial bar basal to cibarial teeth line with many separated prickles decreasing in size toward base of this surface. Cibarial dome nearly

\footnotetext{
* Supported by Grant MVR-BR-2-83-6 - National Academy of Sciences, Washington, D.C., USA

* Department of Epidemiology, School of Public Health, University of S.Paulo - Av. Dr. Arnaldo, 715 - 01255 - São Paulo, SP - Brazil.
} 
FORATTINI, O.P. \& SALLUM, M.A.M. Studies on some species of Culex (Melenoconion), with the description of a new one from Southern Brazil (Diptera: Culicidae). Rev. Saúde públ., S.Paulo, 21 :123-56, 1987.

circular, concave cap entirely built by superficial sharp pointed denticles. Thorax. - Integument with tonality variable from clear to dark brown. Scutum covered by small narrow curved scales, with variable tone from dark chestnut brown to almost black, always bronzy sheen; scutal setae developed, dark brown with golden or reddish shining; acrostichal setae absent. Scutellar scales like scutal ones; lateral scutellar lobes with 3,4 lengthy setae each, medium scutellar lobe with 4.6 lengthy setae. Antepronotum without scales, with scattered dark setae. Postpronotum with scales like scutal ones; posterodorsal margin with 3.4 long dark setae. Pleural integument with similar tonality or little paler than scutum; pleural setae golden of dark chestnut brownish, almost black on the prealar knob; pleural setae 3.5 superior proepistemal, 4,5 prealar, 6.10 superior mesokatepisternal, 5.9 inferior mesokatepisternal, 4.9 superior mesepimeral and 1 or occasionally 2 inferior mesepimeral. Pleura with small patch of pale spatulate scales on posteroinferior margin of mesokatepisternum, occasionally with 2,3 pale scales near superior mesepimeral setae (Fig. 2E). Wing. (Figs. 2C,D) - Length $2.1-2.6 \mathrm{~mm}$, mean $2.41 \mathrm{~mm}$; scales dark; cell $R_{2}$ nearly 3.5 of $R_{2+3}$; cell $M_{1}$ nearly 0.7 of cell $R_{2}$; subcosta reaching costa at level of $\mathbf{R}_{\mathbf{2}+3}$ furcation. Dorsal scaling: appressed spatulate scales on costa, subcosta, $R, R_{1}, R_{4}+5$, distal 0.6 of $M_{1}, M_{2}, M_{3}+4, \mathrm{mcu}$, CuA and 1A; linear plume scales on $R_{S}, R_{2}+3$, $M, M_{1}+2$ and proximal 0.4 of $M_{1}$; inclined narrow spatulate scales on $R_{2}$ and $R_{3}$; remigium with appressed spatulate scales and 2,3 distal strong setae. Ventral scaling: appressed spatulate scales on costa, subcosta, $\mathbf{R}_{S}, \mathbf{R}_{2}+{ }_{3}, \mathbf{M}, \mathbf{M}_{1}+2$ and proximal 0.4 of $\mathrm{M}_{1}$; linear plume scales on proximal 0.5 of $R_{1}$, proximal 0.5 of $R_{4}+5, M_{3}+4$, mcu, $\mathrm{CuA}$ distal to mcu and in middle of $1 \mathrm{~A}$; inclined, narrow spatulate scales on distal 0.5 of $R_{1}, R_{2}, R_{3}$, distal 0.5 of $R_{4+5}$, distal 0.6 of $M_{1}, M_{2}$, and distally on $1 A_{\text {; }}$ $\mathrm{CuA}$ before mcu and proximal 0.5 of $1 \mathrm{~A}$ devoid of scales. Halter. - Scabellum, ventral and anterodorsal parts of pedicel, 'pale; capitellum and posterior extremity of pedicel dorsal part, dark. Legs. - Anterior surface of forecoxa dark-scaled; anterior surfaces of mid and hindcoxae with longitudinal patch of pale scales. Antero-and posteroventral surfaces of foretrochanter dark-scaled; midtrochanter with anteroventral surface dark-scaled, sometimes pale-scaled, posteroventral surface pale-scaled; hindtrochanter with antero-and posteroventral surfaces pale-scaled. Fore-and midfemora almost entirely covered with dark scales, posterior surface of forefemur with longitudinal indistinct patch of pale scales, posteroventral of midfemur with some yellowish scales; hindfemur with dorsal line of dark scales distally widening and expanding on anterior and posterior aspects of apex. Tibiae and tarsi entirely dark-scaled. Abdomen. - Tergum I with distinct median posterior patch of dark scales; terga II-VII dark-scaled, with basolateral patches of pale scales; tergum VIII dark-scaled. Sterna II-VII with wide basal pale band; sternum VIII without scales or with small lateral patches of pale scales. Genitalia. (Fig. 3) - Tergum IX narrow, posterolateral margin widened and with about 3 lengthy setae on each side. Upper vaginal sclerite as an inverted, $U$-shaped, well sclerotized. Postgenital lobe trapezoidal, distally widened, bearing about 10 slender setae on either midline side, mostly on ventral surface. Upper vaginal lip narrow, distinct; insula indistinct, with cluster of about 12 insular setae.

MALE. - Like female except for sexual differences presented as follow (Fig. 2F). Head. - Antenna strongly plumose, length about $1.6 \mathrm{~mm}$. Proboseis entirely dark. Maxillary palpus dark, length about $2.1 \mathrm{~mm}$, exceeding proboscis tip by apical 0.5 of palpomere 4 and all palpomere 5 ; palpomeres 4 and 5 entirely covered with strong setae; palpomere 3 with 3.6 strong apical setae. Abdomen. - Tergum II entirely dark or with few basolateral pale scales; terga III and VII with small basolateral pale-scaled patches; terga IV-VI with basolateral pale-scaled patches that may join forming basal band of variable width; tergum VIII (ventral in position) with deep $V$-shaped median posterior emargination, bearing numerous long strong setae mixed with shorter slender setae (Fig. 3);Genitalia. (Fig. 3). - Tergum IX lobes columnar shaped, well separated basally and slightly convergent apically, roundly or rectangularly outlined, and bearing slender scattered setae. Gonocoxite stocky obovoid shaped, outer margin convex, inner moderately concave; ventrola. teral surface with dark strongly developed setae, mesal surface with several indistinct rows of small setae extending from base to level of subapical lobe; lateral surface with setal patch (lsp) constituted by 5.17 short slender setae at apical region corresponding to level of subapical lobe; proximal part of ventrolateral surface with scales; subapical lobe clearly divided, divisions distinctly separated; proximal division subdivided in to 2 almost parallel arms, basal shorter, distal longer, thickish and apically enlarged, each with 1 long apical sinuous seta ( $a$ and $b$ setae); distal division with 8 setae, 1 long hooked seta $(h)$, 1 short and 1 long saberlike setae (s), 1 slender seta (1), and 4 narrow appressed flat setae slightly different in length $(f)$ and disposed as pages of book. Gonostylus slender, curved, moderate distally widened, crest slightly wrinkled on ventral surface before apical snout; gonostylar claw short, leaf-like, apically broadest. Phallosome with lateral plate and aedeagal sclerite equivalent in length; aedeagal sclerite narrow and curved, anterior margin thickened and sclerotized, dorsal end united to base of lateral plate; distal end of lateral plate with apical, lateral and ventral 
processes, apical one large quadrangular shaped with apical margin dentate with some small teeth on process surface too, lateral process lengthy, slender, tapered, pointed and dorsolaterally directed, ventral process short, blunt and laterally curved; base of lateral plate with dorsal process stout and basally continuous with thickened margin of aedeagal sclerite; aedeagal sclerites not connected by dorsal aedeagal bridge. Proctiger elongate; paraproct distally narrowed, basally expanded at point of articulation with basal plate and posterolateral margin of the tergum $\mathrm{X}$, crown with nearly 12 short, rectangular simple blades; cercal sclerite narrow, lightly sclerotized; 2.3 very small cercal setae; tergum $X$ somewhat rectangular, concave-convex, dorsal surface concave.

PUPA. (Fig. 4) - General chaetotaxy as figured; range and modal number of branches presented in Table 1. Cephalothorax - Diffusively pigmented; legs, scutum and metathorax, with dark areas. Seta 1-CT lengthy, with 4,5 branches, sometimes with $6 ; 2 . \mathrm{CT}$ with 4.6 branches; $3 . \mathrm{CT}$ with 2.4 branches; 4 -CT double or with 3 branches; 5-CT more frequently with 6 , occasionally with 4 branches; 6-CT with 2,3 branches; 7-CT lengthy, double, occasionally with up to 4 branches; 8-CT with 3.7 branches, more frequently with $4 ; 9-\mathrm{CT}$ with 2,3 branches; $10-\mathrm{CT}$ usually with 12 branches (7-17); 11-CT single, lengthy; 12 -CT usually with 3 branches. Trumpet. - Moderately tanned; slender, lightly funnel-shaped; index 6.6-9.7, mean 8.3; tracheoid area extending 0.5 from base; pinna developed, triangular outlined, about 0.3 length of trumpet, lateral margin dentate. Abdomen. - Ligh tly pigmented, lateral margin of tergum I darker, anterior margin of terga II-V more pigmented, terga VI.VIII darker than others; length $1.8 \cdot 2.2 \mathrm{~mm}$, mean $2.0 \mathrm{~mm}$. Setae $1-\mathrm{III} \cdot \mathrm{V}$ multiple; $2-\mathrm{III} \cdot \mathrm{V}$ small and single, mesal to seta $1,2-$ VI, VII small and single, lateral to seta $1 ; 3-I$ single, occasionally double, 3.II frequently double, occasionally single or with 3 branches, 3-III usually double; 5.IV-VI shorter than length of following tergum, 5.IV with 6.10 branches, $5 . \mathrm{V}$ with 6.9 branches, $5 . \mathrm{VI}$ with 2.5 branches; 6-III-VI usually with 4 branches; 9 -VII relatively short, usually double, sometimes triple, 9-VIII more developed scarcely aciculate, inserted on ventral surface, with 3.5 branches. Posterolateral angle of tergum VIII moderately acute. Genital lobe. - Diffusively pigmented in female, darker in male; length about $0.1 \mathrm{~mm}$ in female, $0.3 \mathrm{~mm}$ in male. Paddle. - Lightly tanned, midrib and buttress darker; midrib strong except at apex; buttress strong only at base; margins smooth; length $0.6 \cdot 0.8 \mathrm{~mm}$, mean $0.7 \mathrm{~mm}$, width $0.4-0.6 \mathrm{~mm}$, mean $0.5 \mathrm{~mm}$, index 1.4-1.7, mean 1.5. Seta 1-P single; $2-\mathrm{P}$ single length about 0.5 from $1 \cdot P$.

LARVA. (Fig. 5) - General chaetotaxy as figured; range and modal number of branches pre- sented in Table 2. Head. - Wider than long; length and width not measured; variably tanned, area of lateralia around compound eyes lighter, indefinite darker patch in posterior area of lateralia. Median labral plate distinct dorsally, anterior margin slightly concave between insertions of seta 1-C. Labiogula longer than broad, basally broader than apically; hypostomal suture complete, extended posteriorly from posterior tentorial pit to collar. Collar poorly developed, heavily pigmented. Dorsomentum triangular shaped with median tooth nearly lozengic shaped, with 6.7 teeth on either side. Seta 1.C spiniform, dark; 2-C absent; 3-C diminute, single; 4-C moderately developed, single or double; 5 -C fanlike, aciculate, with 4.8 branches; 6-C long, single lightly aciculate; $8 \cdot 10 \cdot \mathrm{C}$ similars, all branched $(2.8)$; $13-\mathrm{C}$ with 3.5 branches, inserted posteriorly to level of $11-\mathrm{C} ; 14-\mathrm{C}$ and $15-\mathrm{C}$ similar, 14-C usually with 4 branches (2-5), 15-C usually with 5 branches (5-7). Antenna. - Length $0.4-0.7 \mathrm{~mm}$, mean $0.5 \mathrm{~mm}$; lightly tanned, with or without dark ring at base and at level of seta 1-A, sometimes extending for all distal region. Scape developed, pedicel weak; part of flagellum proximal to seta 1 -A curved and scattered spiculose with aciculae more developed basally, distal part thinner with only few aciculae lateral to seta $1 \cdot A$; seta $1 \cdot A \quad 0.7$ from base; antennal puncture distinct. Seta 1.A large, with 23.33 branches, heavily aciculate. Thorax. - Integument hyaline, covered with tiny spicules that are more conspicuous laterally; tubercles of large setae moderately tanned, setae 1-3-P and 9-12-P, M, T inserted on common tubercles. Prothorax. - Setae 1,2.P lengthy, single; $3 \cdot \mathrm{P}$ about 0.3 of $1,2 \cdot \mathrm{P}$, with 5.9 branches; 4-6-P single; 7-P with 2.4 branches; 8-P double. Mesothorax. - Seta 1-M developed, fanlike, usually with 5 branches (4-7); 2 -M much shorter than $1-\mathrm{M}$, usually with 5 branches, occasionally with 3 branches (3-5); 5-M lengthy, single, occasionally double. Metathorax. - Seta 1.T small with 2.4 branches; 5 - T usually with 2 branches, sometimes with 3 branches $(1-3) ; 13-\mathrm{T}$ similar to $1-\mathrm{M}$, usually with 6 or 7 branches (5-8). Abdomen. - Integument hyaline, with minute scattered spicules more evident laterally; setae 6-I, II, 7.1 and II, 3.VIII inserted on moderately tanned tubercles. Segments I-VI: Setae 1-I, II slender, 1-I usually triple (2-4), 1-II frequently double, 1-III-VI developed, fanlike, 1-III usually with 5 branches (4-6), 1-IV, $\mathrm{V}$ frequently with 6 branches, 1-IV with 5.7 branches, $1 . \mathrm{V}$ with 5.8 branches, $1 . \mathrm{VI}$ with 4.7 branches; $2-1$ single or double, $2-11$ single; $6 \cdot I$ lengthy, double, $6 \cdot$ II double, similar to $6 \cdot 1$, 6 -III.VI shorter, developed, usually with 3,4 branches, 6 -III with 3.5 branches; 7-I lengthy, single, 7.II.V smaller, multiple branched $(5 \cdot 10), 7 \cdot \mathrm{VI}$ usually triple $(2.4)$; 13-III.V developed, fanlike, 13-III, IV usually with 4 branches $(3.5) ; 13 . \mathrm{V}$ 
with 4.6 branches. Segment VII: Seta 1 -VII developed, with 6-9 branches; 4.VII lengthy, single; 7-VII double or triple; 10 -VII double, occasionally single; 13-VII developed, with 4-8 branches. Segment VIII: Comb with 36.49 scales, mean 43 ; scales short, fringed on sides and apex, apical fringe more conspicuous than the lateral; scales arranged in 4 roughly irregular rows, nearly triangular in outline; seta 2 -VIII slender and lengthy, usually single. Siphon. - Index 5.4 - 7.2 (width measured at base), mean 6.3; variably tanned, usually lightly, with darkened ring at base and occasionally near middle; acus dark, attached, long and slender on anterior side of attachment. Pecten of $16-20$ spines, mean 18 , increasing in size distally, distal' ones little more widely spaced; ventral margin of spines occupied by fringe with numerous small closely-set denticles. Seta 1-S usually in 7 pairs (in 19 siphons examined, 3 with 6 pairs, 13 with 7 pairs, 1 with 8 pairs, 1 with 6.5 pairs, 1 with 7.5 pairs), 6 posterior pairs (la, c, d, e, g-S) with length of 2 proximals nearly $2.5,2$ medians nearly 2.0 and 2 distals nearly 1.5 width of siphon at point of insertion, 2 anterior pairs (lb, $f-S$ ) as long as width of siphon at point of insertion; seta $2-S$ inserted in membrane near base of antero-lateral spiracular lateral lobe, anteriorly curved with slender curved secondary branch at basal fourth of curved side. Segment $X$ : Saddle complete, without acus, with distinct spicules on dorsal and lateral areas at posterior end; mean length $0.3 \mathrm{~mm}$, siphon/saddle index $3.6-4.1$, mean 4.0. Seta $1-X$ with 3.5 branches; $2 \cdot X$ with 1 long branch and 1 or 2 shorter, developed, sometimes with length 0.5 or more than first; $3-\mathrm{X}$ long, single; 4-X usually with 6 paired setae, rarely with 11 or 13 setae, 3 anterior pairs usually with 4 branches (1-6), 3 posterior pairs most often with 5 branches (4-7), all setae borne on grid, anterior end of grid attached to saddle. Anal papillae slender gradually tapering to blunt tip, dorsal pair shorter than ventral pair, dorsal pair as long as saddle.

MATERIAL EXAMINED. - The specimens examined numbered 217 as follows. Females. - 10 with associated pupal and larval exuviae (Cubatão, Cananéia, IX.83, 2; Experimental Station, Pariquera-Açú, IX.83, IV.84, 5; Pariquera-Mirim, Pariquera-Açú, XI.83, II.83, 2; Fonte, Itapitangui, Cananeia, IX.85, 1). Males. - 18 with associated pupal and larval exuviae (Experimental Station, Pariquera-Açú, III.83, IX.83, IV.84, III.85, 6; Pariquera-Mirim, Pariquera-Açú, VII.83, IX.83, XI.83, II. 85,11 ; Cubatão, Cananéia, IX.83, 1); 189 collected as adult stage (Pariquera-Açú, urban area, VI.76, I.79, II.79, III.79, IV.79, V.79, VI.79, IX.79, X.79, II.81, VI.82, VII.82, VIII.82, 130; Experimental Station, Pariquera-Açú, IX.77, XII.77, I.78, II.78, III.78, IV.78, II.79, III.79, IV.79, IX.79, XII.79, I.80, II.80, III.80, IV.80, I.81, II.81, III.81, VI.81,
39; Ariri, Cananéia, III.80, 1; Taquari, Cananéia, IV.80, 1; Itapitangui village, Cananéia, XI.80, II.81, III.81, XII.81, I.82, 15; Itapuan, Itapitangui, Cananéia, XI.81, 1.82, 2; Fazenda Santa Helena, São João da Boa Vista, II.83, 1).

DISTRIBUTION AND BIONOMICS. - The available data about Culex oedipus supports the supposition that this species is most widespread in the Southeastern region of South America, although the Catalog of Knight and Stone (1977) record this species up to Panama. All the other records include several localities of Argentina and Brazil (Lane, 1953, Oliveira, 1984, Mitchell and Darsie, 1985). Probably the geographical area of the Tropical Atlantic System, seems to represent its main distribution range, including regions both near to and far from the Atlantic Coast.

The species was predominantly found in modified manmade environments, represented by artificially open lands (Fig. 1A). Breeding places were found in these situations, associated with grown land vegetation, mainly grasses and hydrophyte or aquatic plants (Fig. 1B, C, D and E). In these places, immature stages were found in biotic sympatry with $C x$. plectoporpe and $C x$. rabelloi. Besides this it will be significant to mark the collection of this mosquito inside small village and urban areas of the region.

DISCUSSION. - Culex oedipus was described by Root (1927), was put in the synonymy of Cx. phlogistus by Dyar (1928), and resurrected by Rozeboom and Komp (1950). The male was redescribed by Duret (1954) and the pupa was described by Garcia and Casal (1965). Based on adult morphology and male genitalia characters, the species was put in the Inhibitator Group (Subgroup Inhibitator), of the Melanoconion Section, by Sirivanakam (1982) following his own scheme of internal classification of the New World subgenus Melanoconion.

Nevertheless, using pupa characters, $C x$. oedipus should be included in the Trifidus Group, once that pupal seta 9.VII has 2,3 branches and not at least 4 branches as in Inhibitator Group; seta 6.III.VI usually has 4 branches (3-5), while there are usually 2,3 in the Inhibitator Group, besides this, seta 3-II-III is usually double (1-3) while it is usually single, in that Group; finally it is remarkable that seta $5 . V$ of $C x$. oedipus has 6.9 branches, while in the Inhibitator Group there are only 4.6 branches. Through larval characters, there are some difficulties for the $C x$. oedipus identification, because seta 2-VIII is usually single, which under the Sirivanakam (1982) scheme is characteristic of the Peccator Group, despite the siphon/saddle index that is more than 3.0. 
In any case, $C x$. oedipus can be identified easily by characteristic aspects of the male genitalia and the female cibarial armature. The former shows the distal arm of the proximal division of subapical lobe (pSL) with a pronounced enlarged apex where the hooked sinuous seta $b$ is inserted. The cibarial armature of the female presents about 10.12 fold-shaped cibarial teeth each connected by transverse bridges, and serrated along the margin laterally with small thorn shaped prominences. Besides this, the dorsal surface of cibarial bar ( $\mathrm{CiB}$ ) shows many small separated prickles. Besides this, pupal seta 9. VII is double or triple and the 9 .VIII is 3.5 branched and aciculate. Larva seta 4.P is single, 13-III-V fanlike and similar to $1-\mathrm{III}-\mathrm{V}$, and $1 . \mathrm{S}$ is at the utmost 2.5 the length of the siphon width at point of insertion.

\section{Culex (Melanoconion) plectoporpe Root}

Culex (Choeroporpa) plectoporpe Root, 1927: 589 (male). Type-locality: Bangu, Rio de Janeiro, Brazil.

Culex (Melanoconion) plectoporpe of Rozeboom and Komp, 1950: 95; Lane, 1953:447; Clastrier, 1970: 467 (resurrected from synonymy with phlogistus); Sirivanakarn and Jakob, 1981: 197 (3 males, San Fernando, Chaco, Argentina).

Adult. - A small dark species closely resem. bling Culex phlogistus but differing in details of male genitalia.

FEMALE. - Almost entirely clothed with dark scales. Head. - Antenna dark, length all about $2.0 \mathrm{~mm}$; flagellum whorls with 6 setae. Proboscis completely covered by dark scales, length 1.4 $1.7 \mathrm{~mm}$, mean $1.6 \mathrm{~mm}$. Maxillary palpus clothed with dark scales, length $0.2-0.3 \mathrm{~mm}$, mean $0.28 \mathrm{~mm}$, about 0.2 of proboscis length. Vertex (Fig. 6F male) with appressed spatulate 'scales; on dorsal surface of the region these scales are dark, dingy white on lateral sides; forked scales dark; some narrow whitish falcate scales along occipital region. Cibarial armature (Fig. 6A, B and Fig. 9CA, CT). - Cibarial bar concave with 5,6 cibarial teeth almost equivalent in size, fold shaped, borne on transverse bar, dorsally bearing large spatulate hyaline rod with posterior margin serrated but with denticles disposed clustered on margin, median and sometimes lateral wider ones, moderately developed thorn-shaped prominences at two extremities of posterior margin, anteriorly each other connected by discreet transversal bridges. Cibarial dome nearly circular, concave cap entirely built of superficial sharp pointed denticles. Thorax. - Integument dark brown. Scutum with fine narrow curved dark brown scales, with bronzy sheen; scutal setae developed, dark brown with reddish sheen; acrostichal setae absent. Scutellar scales like scutal scales; lateral scutellar lobes with $\mathbf{3 . 5}$ lengthy setae each, medium scutellar lobe with 5 long setae. Antepronotum without scales, with scattered dark setae. Postpronotum with scales like scutal scales; posterolateral margin with 3,4 dark setae. Pleural integument clearer than or similar to the scutal one, pleural setae chestnut brown golden sheen, darker on the prealar knob; pleural seta: 3.8 superior proepisternal, 4.6 prealar, 6.8 superior mesokatepisternal, 7,8 inferior mesokatepisternal, 4-8 superior mesepimeral and 1 inferior mesepimeral. Pleura with small patch of pale spatulate scales on posteroinferior margin of mesokatepisternum, sometimes with 2.3 colorless scales on mesokatepisternum superior angle (Fig. 6E). Wing. (Fig. 6C, D) - Length $2.2-$ $2.8 \mathrm{~mm}$, mean $2.5 \mathrm{~mm}$; scales dark; cell $\mathrm{R}_{2}$ nearly 3.0 of $R_{2}+3$; cell $M_{1}$ nearly 0.7 of cell $R_{2}$; subcosta reaching costa at level of $R_{2}+3$ furcation. Dorsal scaling: appressed spatulate scales on costa, subcosta, $R, R_{1}, R_{4}+5$, distal 0.7 of $M_{1}, M_{2}, M_{3}+4, m c u$, CuA and 1A; linear plume scales on $R_{S}, R_{2}+3, M$, $M_{1+2}$; inclined narrow spatulate scales on $R_{2}, R_{3}$ and basal 0.3 of $M_{1}$; remigium with appressed spatulate scales and 2.3 distal long setae. Ventral scaling: appressed spatulate scales on costa, subcosta, $R_{S}, R_{2+3}, M, M_{1+2}$ and basal 0.3 of $M_{1}$; linear plume scales on proximal 0.5 of $R_{1}$, proximal 0.4 of $R_{4}+5, M_{3}+4$, mcu, CuA beyond mcu and middle of $1 \mathrm{~A}$; inclined narrow spatulate scales on distal 0.5 of $R_{1}$, distal 0.6 of $R_{4}+5$, distal 0.7 of $\mathrm{M}_{1}, \mathrm{M}_{2}$ and distal part of $1 \mathrm{~A}$; CuA before mcu and proximal 0.5 of $1 \mathrm{~A}$ without scales. Halter. - Scabellum, ventral and dorsal parts of pedicel, pale; capitellum and posterior end of pedicellum dorsal region, dark. Legs. - Anterior surface of forecoxa dark-scaled; anterior surfaces of mid and hindcoxae with longitudinal patch of nearly colorless scales. Antero-and posteroventral surfaces of foretrochanter dark-scaled; midtrochanter with anteroventral surface dark-scaled, posteroventral pale-scaled; hindtrochanter with antero-and posteroventral surfaces pale-scaled. Fore-and midfemora almost entirely covered with dark scales, forefemur with indistinct longitudinal patch of dingy pale scales on posterior surface, midfemur with posteroventral surface pale-scaled, hindfemur with longitudinal patch of dark scales distally widening and expanding on anterior and posterior tip surfaces. Tibiae and tarsi entirely dark. Abdomen. - Tergum I with median posterior patch of dark scales; terga II -VII clothed with dark scales, with basolateral patches of pale scales; tergum VIII dark-scaled. Sterna II-VII with wide basal pale band; sternum VIII usually without scales or sometimes with small lateral patches of pale scales. Genitalia (Fig. 9). - Tergum IX narrow, posterolateral with two small lobes bearing a few slen. der scattered setae, nearly 4.6 on each side. Upper vaginal sclerite inverted, U-shaped, well quitinized. Postgenital lobe wide, clearly, rounded on distal 
margin with almost 9 long setae on either midline side, mostly on ventral surface. Upper vaginal lip narrow, distinct; insulà indistinct, with cluster of about 8 insular setae.

MALE. - Like female except for sexual differences presented as follow. Head (Fig. 6F). - Antenna strongly plumose with length about $1.6 \mathrm{~mm}$. Proboscis dark. Maxillary palpus dark, length about $2.3 \mathrm{~mm}$, exceeding proboscis tip by apical 0.5 of palpomere 4 and palpomere 5; palpomeres 4 and 5 entirely covered by strong setae; palpomere 3 with 2.8 strong apical setae. Abdomen. - Tergum II entirely dark or with basolateral pale scales; terga III-VII dark with basolateral pale-scaled patches; tergum VIII (ventral in position) with a deep $V$-shaped median posterior emargination and bearing several long bristles mixed with shorter slender setae (Fig. 7). Genitalia (Fig. 7). - Tergum IX lobes large, obovoid shaped and with smooth basal medially directed projection, remaining surface with numerous slender setae. Gonocoxite stocky obovoid shaped, outer margin convex, inner margin moderately convex; ventrolateral surface with strongly developed setae mixed with smaller others, mesal surface with almost 7 indistinct rows of small slender setae extending from base to level of subapical lobe, lateral surface with setal patch (1sp) formed by numerous long slender setae extending from base to level of subapical lobe; proximal part of ventrolateral surface with scales; subapical lobe clearly divided, divisions distinctly separated; proximal division subdivided in 2 divergent arms, of nearly equal length, each with 1 long apical sinuous seta ( $a$ and $b$ setae); distal division with 7 setae, 1 long hooked seta $(h), 1$ short and 1 long saberlike setae $(s), 1$ wide foliform seta $(l)$, and 3 narrow appressed flat setae subequal in length $(f)$, two narrower with hooked tip, one larger with falciform tip. Gonostylus slender, curved, moderately widened distally, ventral surface with small triangular lapel-shaped fold laterally directed, crest short, minute, wrinkled and extending on ventral surface from fold to apical snout; gonostylar claw short, leaf-like, broadest apically. Phallosome with lateral plate and aedeagal sclerite equivalent in length; aedeagal sclerite narrow and curved, anterior margin thickened and sclerotized, dorsal end united to base of lateral plate; distal end of lateral plate with apical, lateral and ventral processes, apical process large, quadrangular shaped with apical margin minutely dentate, lateral process lengthy, stout, tapered and dorsolaterally directed, ventral process lengthy, blunt and slightly curved laterally; base of lateral plate with dorsal process stout and basally continuous with thickened margin of aedeagal sclerite; aedeagal sclerites not connected by dorsal aedeagal bridge. Proctiger elongate; paraproct narrowed distally, basally expanded at articulation with basal plate and posterolateral margin of tergum $\mathrm{X}$, crown with nearly II short, rectangular simple blades; cercal sclerite narrow, stripe like lightly sclerotized; $2-3$ small cercal setae; tergum $X$ large, somewhat tectangular, concave-convex, dorsal surface concave.

PUPA (Fig. 9). - General chaetotaxy as figured; range and modal number of branches presented in Table 3. Cephalothorax. - Diffusively pig. mented; legs, scutum and metathorax darker. Seta 1-CT lengthy, usually with 5 branches (4-6); 2 -CT double, sometimes with 3 or 4 branches; 3 .CT with $5-8$ branches; 4-CT usually triple, sometimes with. $2-5$ branches; $5-\mathrm{CT}$ with 5.8 branches; $6-\mathrm{CT}$ usually double, sometimes simple or with 3 branches; 7 -CT with 2.4 branches; $8 . \mathrm{CT}$ with 4.8 branches; $9 . \mathrm{CT}$ usually double, sometimes 3,4 branches; $10 . \mathrm{CT}$ usually with 10 branches $(9.24) ; 11 . C T$ single, lengthy, 12-CT with 3,4 branches. Trumpet. - Moderately tanned; slender, nearly cylindrical; index 6.4 - 11.3, mean 8.5; tracheoid area extending 0.5 from base; pinna small, triangular outlined, about 0.2 length of the trumpet, lateral margin slightly dentate. Abdomen. - Lightly pigmented, anterior margin of terga darker more evidently on II-V; length $1.9-2.6 \mathrm{~mm}$, mean $2.1 \mathrm{~mm}$. Setae 1-III.V multiple; 2 -III-V small and single mesal to seta $1,2 \cdot$ VI.VII small and single lateral to seta 1; 3-I single, 3-II frequently double, occasionally single, 3-III double; 5-IV.VI shorter than length of following tergum, 5.IV usually with 9 branches, seldom with 11 branches, $5 . V$ with 7.10 branches, 5-VI with 3.7 branches; 6-III usually with 4 branches, 6.IV.VI usually with 5 branches (4.6); 9 .VII single and stout, 9.VIII single or double, stout, inserted on ventral surface. Posterolateral angle of tergum VIII acute. Genital lobe. - Diffusively pigmented in female, darker in male; length about $0.2 \mathrm{~mm}$ in female, $0.3 \mathrm{~mm}$ in male. Paddle. - Lightly tanned, midrib and buttress darker; midrib strong except at apex; buttress strong only at base; margins smooth; length $0.6-0.8 \mathrm{~mm}$, mean $0.7 \mathrm{~mm}$, width $0.5-0.6 \mathrm{~mm}$, mean $0.5 \mathrm{~mm}$, index $1.1-1.6$, mean 1.3 Seta 1.P single; 2-P single, shorter than 1-P.

LARVA (Fig. 10). - General chaetotaxy as figured; range and modal number of branches presented in Table 4. Head. - Wider than long; length and width not measured; variably tanned, area of lateralia around compound eyes lighter, darker bands in posterior area of lateralia and dorsal apoteme without pattern. Median labral plate distinct dorsally, anterior margin slightly concave between insertions of seta 1-C. Labiogula longer than broad, broader basally than apically; hipostomal suture complete, extending posteriorly from posterior tentorial pit to collar. Collar poorly developed, heavily pigmented. Dorsomentum nearly triangular with large median tooth, and 6.7 teeth on either side. 
Seta 1-C spiniform, dark; $2,3-\mathrm{C}$ absent; 4-C moderately developed with 1.3 branches; $5 . C$ scarcely aciculate, with $6-10$ branches; $6-\mathrm{C}$ long, single, lightly aciculate; $8 \cdot 10-\mathrm{C}$ is similar, all branched (4-10); 13-C with 3,4 branches, inserted posteriorly to level of $11 . \mathrm{C} ; 14 \cdot \mathrm{C}$ and $15 \cdot \mathrm{C}$ are similar, inserted nearly at same level, 14-C usually with 4 branches (3-6), 15-C usually with 5 branches (4-6). Antenna. - Length $0.5-0.7 \mathrm{~mm}$, mean $0.6 \mathrm{~mm}$, equivalent to length of head; lightly tanned, with dark ring at base and at level of seta 1-A. Scape developed, pedicel weak; part of flagellum proximal to seta 1-A curved with scattered spicules, distal part thinner with only a few aciculae lateral to seta 1 -A; seta 1-A 0.8 from base; antennal puncture distinct. Seta 1-A large, with $22-31$ branches, heavily aciculate; 4-A short, less than 0.5 of 2,3-A. Thorax. - Integument hyaline, covered with tiny spicules that are more conspicuous laterally; tubercles of large setae moderately tanned, setae 1-3-P and 9.12.P, M, T inserted on common tubercles. Prothorax. - Setae 1,2-P lengthy, single;3-P about 0.3 length of $1,2-P$ usually with 8 branches, rarely with 7 branches $(7-10)$; 4-P double; 5,6-P single; 7.P with 3.5 branches; 8-P double or triple. Mesothorax. - Seta 1-M developed, fanlike, usually with 6 branches $(5-7) ; 2 \cdot \mathrm{M}$ shorter than $1 \cdot \mathrm{M}$, with 3.6 branches; $5 \cdot \mathrm{M}$ lengthy and single. Metathorax. - Seta 1-T small, with 3.6 branches; 5.T single or double; $13 . \mathrm{T}$ fanlike, similar to $1-\mathrm{M}$, with 7-10 branches. Abdomen. - Integument hyaline, with minute spicules, more developed on posterior segments; setae 6-I, II, 7-I and 2, 3.VIII inserted on moderately tanned tubercles. Segments I-VI: Setae 1-I, II slender, 1-I usually triple (2-6), 1 -II usually double (2-4), 1 -III-VI developed, fanlike, 1 -III with 4.8 branches, 1. IV, VI frequently with 6 branches, $1 . \mathrm{V}$ with 5.10 branches; $2-\mathrm{I}$ single or double, 2-II single; 6-I, II lengthy, double, 6-III-VI shorter, usually with 4 or 5 branches, 6 -III with 3.6 branches, 6 -IV, VI with 4.6 branches, $6 . \mathrm{V}$ with 4,5 branches; 7 -I lengthy, single, $7-\mathrm{II} \cdot \mathrm{V}$, smaller, multiple, 7-II with 4.7 branches, 7-III usually with 10 branches $(6-10) ; 13 \cdot$ III $-\mathrm{V}$ fanlike, 13-III-IV usually with 4 branches, 13.V usually with 5 branches (4-7). Segment VII: Seta 1-VII developed, with 6.10 branches; 4 .VII lengthy, single sometimes double; 7 .VII double or triple; 10-VII double, occasionally triple; 13 .VII with 6.8 branches. Segment VIII: Comb with 36.47 scales, mean 42; scales short, fringed on sides and apex, fringe more conspicuous apically than lateraly; scales arranged in 4 roughly irregular rows, nearly triangular in outline; seta 2-VIII slender and lengthy, double. Siphon. - Index 5.6 - 6.7 (width measured at base), mean 6.3; moderately tanned, with darkened ring at base and frequently near middle; acus dark, attached, long and slender on anterior side of attachment. Pecten with 17.21 spines, mean 19 , increasing in size distally, distal ones little more widelly spaced; ventral margin of spines occupied by fringe with numerous small closely-set denticles. Seta 1.5 usually in 7 pairs (in 14 examined siphons, 2 with 6.5 pairs, 7 with 7 pairs and 5 with 7.5 pairs), 6 posterior pairs $(1 \mathrm{a}, \mathrm{c}, \mathrm{d}, \mathrm{e}, \mathrm{g} \cdot \mathrm{S})$ with length of 2 proximals nearly $2.4,2$ medians nearly 2.2 and 2 distals nearly 1.5 width of siphon at point of insertion, 2 anterior pairs $(1 \mathrm{~b}, \mathrm{f}-\mathrm{S})$ as long as width of siphon at point of insertion; seta 2-S inserted in membrane near base of anterolateral spiracular lobe, anteriorly curved with slender curved secondary branch inserted at basal fifth of curved side. Segment $X$ : Saddle complete, without acus, with distinct spicules on dorsal and lateral posterior areas; mean length $0.3 \mathrm{~mm}$, siphon/ saddle index $3.2 \cdot 4.0$, mean 3.7 . Seta $1 \cdot \mathrm{X}$ with 3.6 branches; $2 \cdot \mathrm{X}$ with 1 long branch and 1 or 2 shorter; $3 \cdot X$ long, single; 4 -X usually with 6 paired setae, rarely with 11.13 setae, 3 anterior pairs usually with 5 branches $(2 \cdot 7), 3$ posterior pairs usually with 6 branches (5-8), all setae borne on grid, anterior end of grid attached to saddle. Anal papillae long, gradually tapering to blunt tip, dorsal pair shorter than ventral pair, dorsal pair 1.7 length of saddle.

MATERIAL EXAMINED. - There were examined 94 specimens as follows. Females. -5 with associated pupal and larval exuviae (Experimental Station, Pariquera-Açú, III.83, IV.84, V.85, VII.85, 5); 2 with associated pupal exuviae (Experimental Station, Pariquera-Açú, 2); 6 associated pupal and larval exuviae (Experimental Station, Pariquera-Açú, III.83, 2; Biguá Road, Iguape, III.84, 3; Pariquera. -Mirim, Pariquera-Açú, II.85, 1); 1 collected as adult stage (Experimental Station, Pariquera-Açú, IV .84). Males. -8 with associated pupal and larval exuviae (Experimental Station, Pariquera - Açú, III.83, IV.84. VII.85, 3; Biguá Road, Iguape, III.84, 2; Pariquera-Mirim, Pariquera-Açú, II .85, 3); 2 with associated pupa! exuviae (Biguá Road, Iguape, VII.84, 1 ; Experimental Station, Pariquera-Açú, 1);67 collected as adult stages (Pariquera-Açú, urban area, 1.79, II.79, III.79, IV.79, V.79, IX.79, X.79, XI.79, XII.79, II.80, XII.80, I.81, IV.82, 50; Experimental Station, Pariquera-Açú, I.79, III.79, I.81, II.81, IV.81, VI.81, 7; Itapuan, Itapitangui Cananéia, indoor, II.81, 1; Itapitangui, village, II.81, IV.82, IX.82, 3; Biguá Road, Iguape, IX.82. XI.82, 4; Iguape, urban area, 1; Pariquera-Mirim, Pariquera-Açú, VII.84, 1). Other specimens. $-1 \mathrm{malc}$ with associated pupal and larval exuviae (Jacarepaguá, Rio de Janeiro State, Brazil, R.L. Oliveira col., V. 82); 2 males of $C x$. phlogistus (Carapajó, Pará State, Brazil, C. Maciel col., VIIl.63, 1; IPEAN, Belém, Pará State, Brazil, A. Toda col., VIl.66, 1).

DISTRIBUTION AND BIONOMICS. - Data of the Catalog of Knight and Stone (1977) indicate this species has a very large geographical distribution, spreading from the North to the Southern 
end of the South American Continent, including Brazil, French Guiana and Panama. However, the close resemblance with $C x$. phlogistus may have given rise to some misidentifications. So, as is presented in the discussion later on, it seems that $C x$. plectoporpe is widespread primarily in the Southern region of South America, the records available including several localities in Argentina and Southeastern Brazil (Lane, 1953, Oliveira, 1984, Mitchell and Darsie, 1985). The Tropical Atlantic System seems to represent the main biogeographical area of this mosquito.

The species was found breeding mainly in ground water in manmade environments, following the modifications of the primitive environment. So artificially opened lands seem to be preferred by $C x$. plectoporpe (Fig. 1A). Breeding places in these situations are represented by artificial ditches, ponds and even small pools on open terrain, all of them associated with land vegetation such as molasses grass (Fig. 1C, D, E and F). In these places, immature stages were found in biotic sympatry with $C x$. oedipus and $C x$. rabelloi. Adults were collected near human settlements, sometimes indoors. Thus, the mosquito was found inside villages in urban areas of the region studied.

DISCUSSION. - Culex plectoporpe was described by Root (1927), put in the synonymy of $C x$. phlogistus by Fauran (1961), and was resurrected by Clastrier (1970). This complex problem started when Senevet and Abonnenc (1939) described the larval stage from one male of Cayenne, French Guyana, identified by them as $C x$. plectoporpe. More recently Fauran (1961) on studying this material, considered the distal lapel-shaped fold of gonostylus (Fig. 7) a mounting artifice, and that this species should be a synonym of $C x$. phlogistus which does not have this character. This mistake was cleared up by Clastrier (1970). Thus, the material of Senevet and Abonnenc (1939) probably belongs to $C x$. phlogistus, as can be observed by the drawings representing of the male genitalia published in this paper. For this reason, the references to immature stages based on that description for Cx. plectoporpe, probably do not belong to this species (Lane, 1953, Foote, 1954, Darsie, 1985). Besides, adult records from Central America (Panama), North of South America and the Amazon region merit a more detailed study (Komp, 1935, Heinemann and Belkin, 1979).

The distinction between the male genitalia of $C x$. plectoporpe and $C x$. phlogistus may be made easily by comparing the gonostylus (Gs), flat setae $(f)$, of the distal division of the subapical lobe (dSL), lateral plate (LP) of aedeagus, and the IX-tergum (Figs. 7 and 8). The gonostyli (Gs) are different in shape, with the distal portion stouter in phlogistus, and with a small lateral lapel-shaped fold in plectoporpe that is lacking in phlogistus. The three $f$ setae of dSL are hooked at the tip in plectoporpe, and blunt at the tip in phlogistus. The apical process of LP is nearly of rectangular or quadrangulate in plectoporpe, while it is trapezoidal or even fanlike in phlogistus. Finally, the IX-tergum has a larger hairless tip area in phlogistus than in plectoporpe.

Besides the characters described above, $C x$. plectoporpe may be identified as follows. In the female the cibarial armature has about 5.6 fold shaped teeth with the bridges, connected to each other very small; the dorsal surface of cibarial bar (CiB) is narrow and without prickles. The pupal setae 9-VII-VIII are strong and smooth, developed, single or double. The larval seta 4-P is double; the $1 \cdot M$ and $3 \cdot M$ setae are equivalent in length and well developed; setae $1 \cdot$ III.V. and $13 \cdot$ III-V are fanlike and equivalent in length. Besides this, the length of $1-\mathrm{S}$ is at most 2.4 the width of the siphon at the point of insertion.

Based on adult morphology and male genitalia characters $C x$. plectoporpe was put in the Inhibitator Group (Subgroup Inhibitator) of the Melanoconion Section of Sirivanakarn (1982). However, as far is known, larval seta 4-P is single in that Group while it is double in this species.

\section{Culex (Melanoconion) rabelloi sp. $\mathrm{n}$.}

Culex (Melanoconion) albinensis of Duret, 1953:74; Duret, 1954:104 (4 males, Colonia Pellegrini, Corrientes and Arroyo Quiá, Presidente Perón [Chaco], Argentina); Sirivanakarn and Jakob, 1981:197 (6 males and 1 female, Rio Negro Bridge, Resistencia, Chaco, Argentina; 1 male, Rio Tragadero nr Antequera, Chaco, Argentina; 1 male, General Paz Dept., Corrientes, Argentina; 2 males, San Cosme Dept., Paso de la Patria, Corrientes, Argentina; 1 male, Vera, Vera Dept., Santa $\mathrm{Fe}$, Argentina; 1 male, Esperanza, Las Colonias Dept., Argentina).

Adult. - A small species closely resem. bling Culex albinensis, but differing in details of the male genitalia, female cibarial armature, and some others details related to pupa and larva.

FEMALE. - Almost entirely clothed by dark brown to black bronzy sheen scales. Head. - Antenna dark, mean length $1.6 \mathrm{~mm}$; flagellum whorls with 6 setae. Proboscis completely covered by dark scales, length about $1.4 \mathrm{~mm}$. Ma. xillary palpus entirely covered with dark scales, length $0.3-0.4 \mathrm{~mm}, 0.2-0.3$ of the proboscis length. Vertex (Fig. 11F, male) with appressed spatulate scales that are dark dorsally and gray laterally; forked scales dark; occipital region with falcate whitish scales; ocular and interocular setae 
dark and lengthy. Cibarial armature (Fig. 11A, B and Fig. 13CA, Ct). - Cibarial bar concave with 5,6 cibarial teeth almost equivalent in size, fold-shaped, borne on the transverse bar, dorsally bearing a large spatulate hyaline rod posteriorly serrated along the margin that bears lateral lengthy thorn-shaped prominences one at each side, anteriorly each connected by transversal bridges. Cibarial dome nearly circular, concave cap entirely built of superficial sharp pointed denticles. Thorax. - Integument dark brown to coppery. Scutum covered with fine narrow coppery sheen brown scales; scutal setae developed, brownish black, golden or coppery shining; acrostichal setae absent. Scutellar scales like scutal ones; lateral scutellar lobes each with 3,4 or sometimes 5 lengthy setae, medium scutellar lobe usually with 6 long setae. Antepronotum without scales, with scattered bronzy setae. Postpronotum with scales like scutal ones; posterolateral margin with 3.5 long dark setae. Pleural integument paler than scutal one, brownish pale or cream-coloured, a little darker on the proepisternum, postspiracular area and prealar knob; pleural setae brown with golden sheen, darker on prealar knob, paler on inferior mesokatepisternum, superior and inferior mesepimeron where they are yellowish; pleural setae: 3.5 superior proepisternal, 4,5 occasionally 3 prealar, $6 \cdot 10$ superior mesokatepisternal, 5-8 inferior mesokatepisternal, 5-9 superior mesepimeral and 1 or occasionally 2 inferior mesepimeral. Pleura with small patch of pale spatulate scales on posteroinferior margin of mesokatepisternum, sometimes with $2-4$ colorless scales on superior angle of mesokatepisternum (Fig. 11E). Wing (Fig. 11C, D). - Length $2.3-2.7 \mathrm{~mm}$, mean $2.5 \mathrm{~mm}$; scales dark; cell $R_{2}$ length nearly 3.0 of $R_{2+3}$; cell $M_{1}$ length nearly 0.7 of cell $R_{2}$; subcosta reach costa at level of $R_{2}+3$ furcation. Dorsal scaling: appressed spatulate scales on costa, subcosta, $R$, $R_{1}, R_{4+5}$, distal 0.6 of $M_{1}$, distal 0.7 of $M_{2}$, $\mathrm{M}_{3+4}, \mathrm{mcu}, \mathrm{CuA}$ and $1 \mathrm{~A}$; linear plume scales on $R_{s}, R_{2+3}, M, M_{1+2}$, proximal 0.4 of $M_{1}$ and proximal 0.3 of $\mathrm{M}_{2}$; inclined narrow spatulate scales on $R_{2}$ and $R_{3}$; remigium with appressed spatulate scales and 2,3 long distal setae. Ventral scaling: appressed spatulate scales on costa, subcosta, $R_{\mathbf{S}}$, $\mathrm{R}_{2+3}, \mathrm{M}, \mathrm{M}_{1+2}$ and proximal 0.3 of $\mathrm{M}_{1}$; linear plume scales on proximal 0.5 of $R_{1}$ and of $R_{4+5}$, proximal 0.7 of $\mathrm{M}_{2}, \mathrm{M}_{3}+4, \mathrm{mcu}$, Cua distal to mcu and on middle of $1 \mathrm{~A}$; inclined narrow spatulate scales on distal 0.5 of $R_{1}, R_{2}, R_{3}$, distal 0.5 of $R_{4+5}$, distal 0.7 of $M_{1}$, distal 0.3 of $M_{2}$ and distal 0.5 of $1 \mathrm{~A}$; $\mathrm{CuA}$ before mcu and proximal 0.5 of 1 A without scales. Halter. - Scabellum, ventral -and dorsal parts of pedicel, pale; capitellum dark. Legs. - Anterior surface of forecoxa dark-scaled; anterior surface of mid-and hindcoxae with a longitudinal patch of coloriess scales. Antero-and posteroventral surfaces of foretrochanter dark- -scaled; midtrochanter with anteroventral surface dark-scaled, posteroventral pale-scaled; hindtro. chanter with antero-and posteroventral surfaces pale-scaled. Fore-and midfemora almost entirely covered with dark scales, forefemur with an indistinct longitudinal patch of pale scales on the posterior surface, midfemur with posteroventral surface pale-scaled, hindfemur with narrow longitudinal patch of dark scales widening distally and expanding on anterior and posterior sides of apex. Tibiae and tarsi entirely dark. Abdomen. - Tergum I with median posterior patch of dark scales; terga II-VIl clothed with dark scales, with basolateral patches of pale scales; tergum VIII dark-scaled. Sterna II-VII with wide basal pale band; sternum VIII usually without scales or sometimes with small lateral patches of pale scales. Genitalia (Fig. 13). - Tergum IX narrow, posterolateral margin with two small lobes, and with 12.14 slender setae on each side. Upper vaginal sclerite inverted U-shaped, well sclerotized. Postgenital lobe wide, distal margin clearly rounded, with about 9 long setae on either side of midline mixed with smaller ones, mostly on ventral side. Upper vaginal lip narrow, distinct; insula indistinct, with cluster of about 8 insular setae.

MALE. - Like female except for sexual differences presented as follows (Fig. 11F). Head. - Antenna strongly plumose with length about $1.5 \mathrm{~mm}$. Proboscis dark. Maxillary palpus dark, length about $2.3 \mathrm{~mm}$, exceeding proboscis tip by apical 0.5 of palpomere 4 and all palpomere 5; palpomeres 4 and 5 entirely covered by strong setae; palpomere 3 with about 5 strong apical setae. Abdomen. - Tergum Il entirely dark; terga III-VII sometimes entirely dark, or terga III dark with small basolateral pale-scaled patches, terga IV.VI brownish dark with basolateral pale. -scaled patches; tergum VIII (ventral in position) with deep V-shaped median posterior emargination, and bearing numerous long bristles mixed with shorter slender setae (Fig. 12); sterna predominantly dark, with basolateral pale scaled patches that may or may not to become basal bands of variable width. Genitalia (Fig. 12). - Tergum IX lobes large, almost elliptical, approximate basally and diverging apically, bearing numerous slender setae. Gonocoxite stocky obovoid shaped, outer margin convex, inner margin moderately concave; ventrolateral surface with strongly developed setae, mesal surface with small slender setae in several indistinct rows extending from base and sometimes scarcely reaching level of subapical lobe, lateral surface with setal patch (1sp) formed of many short slender setae at apical region up to level of subapical lobe; proximal part of ventrolateral surface with scales; subapical lobe clearly divided, divisions distinctly separated; proximal division subdivided in 2 divergent arms, 
basal arm slightly shorter, each with 1 long apical sinuous seta ( $a$ and $b$ setae); distal division with 8 setae, 1 long hooked seta $(h), 1$ short and 1 long saberlike setae $(s), 1$ slender seta $(\ell)$, and 4 narrow appressed flat setae of different lengths $(f)$. Gonostylus slender, curved, moderately widened distally, crest slightly wrinkled on ventral surface before apical snout; gonostylar claw short, leaf-like, broadest apically. Phallosome with lateral plate and aedeagal sclerite of equal in length; aedeagal sclerite narrow and curved, anterior margin thickened and sclerotized, dorsal end united to base of lateral plate; distal end of lateral plate with apical, lateral and ventral processes, apical one large, trapezoid or with fan outline, apical margin well dentate, lateral process lengthy, slender, tapered, pointed and dorsolaterally directed, ventral process lengthy, blunt and laterally curved; base of lateral plate with dorsal process stout and basally continuous with thickened margin of aedeagal sclerite; aedeagal sclerites not connected by dorsal aedeagal bridge. Proctiger elongate; paraproct distally narrowed, basally expanded at point of articulation with basal plate and posterolateral margin of tergum $X$, crown with nearly 11 short, rectangular simple blades; cercal sclerite narrow, lightly sclerotized; 2.3 small cercal setae; tergum $X$ large, somewhat rectangular, concave-convex, dorsal surface concave.

PUPA (Fig. 13). - General chaetotaxy as figured; range and modal number of branches presented in Table 5. Cephalothorax. - Slightly pigmented; legs, scutum and metathorax with darker areas without pattern. Seta 1-CT lengthy with 3.6 branches, usually $4 ; 2$-CT with 5,6 branches rarely $9 ; 3 \cdot \mathrm{CT}$ with 2,3 branches; $4 \cdot \mathrm{CT}$ with 2.4 branches; 5.CT usually with 7 branches, range $4 \cdot 10 ; 6$ - CT double, sometimes simple or with up to 4 branches; 7.CT lengthy, usually double, sometimes with 3,4 branches; 8 -CT with 4.9 branches; 9.CT usually double, sometimes single with up to 4 branches; $10 . \mathrm{CT}$ slightly aciculate with 8.16 branches; 11-CT single, lengthy; $12 . \mathrm{CT}$ with 2.5 branches, seldom double. Trumpet. - Moderately tanned; slender, slightly funnel-shaped; index 5.6 - 9.1, mean 7.7; tracheoid area darker, extending 0.5 from base; pinna large, triangular, about $0.2-0.3$ of trumpet length, lateral margin dentate. Abdomen. - Lightly pigmented; length $1.7-2.3 \mathrm{~mm}$, mean $2.0 \mathrm{~mm}$. Setae $1-\mathrm{III} \cdot \mathrm{V}$ multiple; $2 \cdot$ III $\cdot V$ small and single, mesal to seta 1 , 2-VI, VII small and single, lateral to seta 1; 3-I single, 3-II, III usually double, occasionally single; $5 \cdot \mathrm{IV}, \mathrm{V}$ almost as long as following tergum, $5-\mathrm{VI}$ little shorter than tergum VII, 5-IV multiple with 6.12 branches, $5 . \mathrm{V}$ usually with 6 branches $(5-11)$, 5.VI multiple with 3.7 branches, rarely $7 ; 6$-III with 3.5 branches, $6 \cdot$ IV.VI with $3 \cdot 7$, rarely with 3 branches; 9 .VIl developed, usually with 3 bran. ches $(2,3), 9$-VIII with 3.5 branches, inserted on ventral surface. Posterolateral angle of tergum VIII acute. Genital lobe. - Diffusively pigmented in female, darker in male; length about $0.1 \mathrm{~mm}$ in female, $0.3 \mathrm{~mm}$ in male. Paddle. - Lightly tanned, midrib and buttress darker; midrib strong except at apex; buttress strong only at base; margins smooth; length $0.6-0.8 \mathrm{~mm}$, mean $0.7 \mathrm{~mm}$, width $0.4-0.5 \mathrm{~mm}$, mean $0.5 \mathrm{~mm}$, index $1.2-1.6$, mean 1.4 . Seta $1 . P$ single; $2-\mathrm{P}$ single about 0.5 length of $1 \cdot \mathrm{P}$.

LARVA (Fig. 14). - General chaetotaxy as figured; range and modal number of branches presented in Table 6. Head. - Wider than long; length and width not measured; variably tanned without pattern, area of lateralia around compound eyes lighter, indefinite darker band in posterior area of lateralia and dorsal apoteme. Median labral plate distinct dorsally, anterior margin slightly concave between insertions of seta 1.C. Labiogula longer than broad, broader basally than apically; hypostomal suture complete, extended posteriorly from posterior tentorial pit to collar. Collar poorly developed, heavily pigmented. Dorsomentum triangular with median tooth and about 6 teeth on either side. Seta 1-C spiniform, dark; $2 \cdot \mathrm{C}$ absent; 3.C stunted; 4.C moderately developed, single or double, occasionally with 3 branches; $5 . \mathrm{C}$ developed, fanlike, aciculate, frequently with 3 branches (2.7); 6.C long, single, aciculate; 8.10.C similar, all branched $(3.8) ; 13-\mathrm{C}$ with 2.4 uranches, inserted posterior to level of 11.C; 14-C usually double $(2.5)$ and similar to $15 . C$ with 4.6 branches. Antenna. - Length $0.4-0.5 \mathrm{~mm}$, mean $0.49 \mathrm{~mm}$; lightly tanned with pigmented rings reduced or even absent at base and level of se ta 1-A. Scape developed; pedicel weak; part of flagellum proximal to seta 1-A curved and spiculose with more basally developed aciculae, distal part thinner with only few aciculae lateral to seta 1.A; seta 1.A $0.7-0.8$ from base; antennal puncture distinct. Seta 1-A large, with 23.31 branches, heavily aciculate. Thorax. - Integument hyaline, covered with developed spicules that are more conspicuous laterally; tubercles of large setae moderately tanned, setae 1-3.P and 9-12.P, M, T inserted on common tubercles. Prothorax. - Setae 1,2-P lengthy, single; $3 \cdot P$ about 0.2 of $1,2 \cdot \mathrm{P}$, with 6.13 branches; $4-\mathrm{P}$ single, occasionally double; 5,6-P lengthy and single; 7-P double or triple, occasionally with 4 branches; 8.P double. Mesothorax. - Seta 1-M developed, fanlike, with 4-8 branches; 2-M shorter than $1 \cdot \mathrm{M}$, with 3.5 branches; $5 . \mathrm{M}$ lengthy and single. Metathorax. - Seta 1-T small, frequently double, occasionally single $(1-5) ; 13-T$ fanlike, similar to $1-\mathrm{M}$, with $5-10$ branches. $A b d o$ men. - Integument hyaline, with scattered minute spicules, more evident laterally; setae 6-I, II, 7-I and 2,3-VIII inserted in moderately tanned tubercles. Segments I.VI: Setae 1-I, II small, single to 
4 branches (1-4), 1-III-VI developed, fanlike, 1. III, VI with 4.9 branches, 1 -IV with 5.10 branches, $1 \cdot V$ with 5.11 branches; $2 \cdot 1$ single, sometime apically forked, 2 -II -VI single; 6 -I double, rarely with 1 branch forked apically, 6-II double, 6-III-VI shorter, developed, usually with 4 branches, 6 -III, V with 3.5 branches, 6 -IV,VI with 3,4 branches; 7.I lengthy, single, 7-II.VI smaller, multiple branched, 7-II with 4.8 branches, 7 -III.V frequently with 7 branches, 7.III with 5.10 branches, 7 -IV with 7.10 branches, $7 . \mathrm{V}$ with 7.9 branches, 7.VI with 3.7 branches; 13-III.V developed, fanlike, $13 \cdot$ III with 3,4 branches, $13 \cdot I V, V$ usually with 4 branches. Segment VII: Seta 1.VII develop. ed, with 7.13 branches; 4 .VII lengthy, single, rarely double; 7 -VII with 2.4 branches; 10 -VII double, 13.VII moderately developed, with 5.7 branches. Segment VIII: Comb with 16.44 scales, mean 30; scales short, fringed on sides and apex, fringe more conspicuous apically than laterally; scales arranged in 4 irregular rows nearly forming triangle; seta 2-VIII slender and lengthy, double. Siphon. - Index 5.6 - 7.3 (width measured at base), mean 6.4 ; variably tanned, usually moderately, with darkened ring at base and frequently near middle; acus dark, attached, long and slender on anterior side of attachment. Pecten of 15.20 spines, mean 18, increasing in size distally, distal ones little widely more spaced; ventral margin of spines with fringe with numerous small closely-set denticles. Seta 1.S usually in 8 pairs (in 21 siphons examined, 9 with 8 pairs, 7 with 7.5 pairs, 3 with 7 pairs and 2 with 6.5 pairs), 6 posterior pairs (la, b, d, e, f, $\mathrm{g}-\mathrm{S}$ ) with length of proximals nearly $3.5,2$ medians nearly 3.0 and 2 distals nearly 2.0 width of siphon at point of insertion, 2 anterior pairs (lc, h-S) as long as width of siphon at point of insertion; seta $2 . S$ inserted in membrane near base of anterolateral spiracular lobe, anteriorly curved with slender curved secondary branch inserted submedially at curved side. Segment $X$. - Saddle complete, without acus, with distinct spicules on dorsal and lateral posterior areas; mean length $0.3 \mathrm{~mm}$, siphon/saddle index 3.3 - 3.7, mean 3.6 . Seta $1 . X$ with 2.6 branches; $2-X$ with 1 long branch and 1 or 2 shorter; $3 \cdot X$ long, single; $4 \cdot X$ with 6 paired setae, 3 anterior pairs with 1.6 branches, 3 posterior pairs with 4.7 branches, all setae bome on grid, anterior end of grid attached to saddle. Anal papillae long, slender, gradually tapering to blunt tip, dorsal pair shorter than ventral pair, dorsal pair as long as saddle.

MATERIAL EXAMINED. - There were examined 73 specimens as follows. Holotype. - Male with associated pupal and larval exuviae, collected in Pariquera-Mirim, Pariquera-Açú County, S.Paulo State, Brazil, 11.II.1985, Coll.O.P. Forattini and col., as a larva from a pond in open land with rushes and aquatic vegetation, deposited in the Entomological
Collection of the Department of Epidemiology of the School of Public Health, University of S.Paulo, Brazil (FSP.USP), (n. E-7311). Paratypes. - $15 \mathrm{ma}$ les and 11 females with associated exuviae, from several localities of S.Paulo State, Brazil. Deposited in the FSP.USP (ns. E-7312 to E-7323): 5 males with associated pupal and larval exuviae (Biguá Road, Iguape, III.84, 2; Pariquera-Mirim, Pariquera-Açú, XI. 84, 1; Itapuan, Itapitangui, Cananéia, XI.84, 1; Subauna, Iguape, VII.85, 1); 2 males with associated pupal exuviae (Experimental Station, Pariquera-Açú, VIII.85); 5 females with associated pupal and larval exuviae (Biguá Road, Iguape, III.84, 4; Subauna, Iguape, VII.85, 1). Deposited in the National Museum of Natural History, Smithsonian Institution, Washington, D.C.: 2 males with associated pupal and larval exuviae (Pariquera-Mirim, Pariquera-Açú, II.85); 1 male associated with pupal exuviae (Subauna, Iguape, VII.85); 3 females with associated pupal and larval exuviae (Biguá Road, Iguape, III.84, 1; Pariquera-Mirim, Pariquera-Açú, XI.84, 2). Deposited in the British Museum (Natural History): 2 males with associated pupal and larval exuviae (Biguá Road, Iguape, III.84, 1; Pariquera-Mirim, Pariquera-Açú, X.84, 1); 1 male with associated pupal exuviae (Subauna, Iguape, VII.85); 2 females with associated pupal and larval exuviae (Biguá Road, Iguape, III.84, 1; Pariquera-Mirim, Pariquera-Açú, XI.84, 1). Deposited in the "Instituto Oswaldo Cruz, Departamento de Entomologia": 2 males with associated pupal and larval exuviae (Experimental Station, Pariquera-Açú, IV.83, 1; Itapuan, Itapitangui, Cananéia, XI.84, 1); 1 female with associated pupal and larval exuviae (Subauna, Iguape, VII.85). 37 males collected as adult stages, from several localities of S.Paulo State, Brazil. Deposited in the FSP.USP (ns. E.7230 to E-7250): 21 (Rio Jacaré-Pipira, Dourado, V. 80, XII.80, III.81, VII.81, X.82, 7; Itapuan, Itapitangui, Cananéia, IV.81, 2; Pariquera-Açú, urban area, XI.79, X.80, 3; Experimental Station, PariqueraAçú, I.81, II.81, 3; Fazenda Santa Helena, São João da Boa Vista, peridomiciliary col., III.82, 1; Biguá Road, Iguape, X.82, 1; Vilarinho, Itapitangui, Cananéia, IV. 83, 1; Pariquera-Mirim, Pariquera-Açú, V.84, 2; Folha Larga, Itapitangui, Cananéia, VIII.84, 1. Deposited in the National Museum of Natural History, Smithsonian Institution, Washington, D.C.: 9 (Experimental Station, Pariquera-Açú, II.80, III.80, II.81, 3; Pariquera-Açú, urban area, VI.80, I.81, II.81, 4; Rio Jacaré-Pipira, Dourado, III.81, $X .82,2)$. Deposited in the British Museum (Natural History): 3 (Rio Jacaré-Pipira, Dourado, IIl.81, 1; Biguá Road, Iguape, XI.82, 1; Pariquera-Mirim, Pariquera-Açú, V.84, 1). Deposited in the "Instituto Oswaldo Cruz, Departamento de Entomologia": 2 (Rio Jacaré-Pipira, Dourado, X.80, IX.82). Other specimens. -10 males of $C x$. albinensis (Utinga, 
Belém, Pará State, Brazil, A. Toda col., III.66, VII. 66, 6; IPEAN, Belém, Pará State, Brazil, A. Toda col., VII.66, 4).

DISTRIBUTION AND BIONOMICS. - Culex rabelloi has a widespread range in Southern South America. The available data on 's geographical distribution include several localılies of Argentina (Mitchell and Darsie, 1985). Pronably it extends as far as the biogeographic dominion of the Tropical Atlantic System. In the brazilian part of this system, the species was found in several localittes of S.Paulo State, and in the coastal area of Rio de Janeiro State (Oliveira, 1984).

The breeding places were found mainly an ground waters in manmade environments, represented by open lands as a consequence of the modifications of the primitive environment (Fig. 1A). Artificial ditches and ponds, and small streamlets in secondary woods (Fig. 1B, D, E), all with densely growing vegetation. Immature stages were found in association with $C x$. oedipus, $C x$. plectoporpe and $C x$. ribeirensis. Adults were collected in human settlements, sometimes in domiciliary environments. So $C x$. rabello $i$ is found frequently inside villages and urban areas of the region studied.

DISCUSSION. - Culex rabelloi is early confused with $C x$. albinensis. It may be distinguished, by the male genitalia, mainly by the aspect of the leaf seta (1) on the distal division of the subapical lobe (dSL), In albinensis this seta is enlarged, saber like as seta (s), while in rabelloi it is slender, and without a saber aspect (Fig. 12). In the female the cibarial armature presents about 5-6 fold-shaped cibarial teeth almost equivalent in size, each con. nected by developed transversal bridges, while in albinensis this armature presents 13.14 narrow teeth (Sirivanakam, 1978). In the pupa, the seta $4 \cdot \mathrm{V}, 5 . \mathrm{IV}, 5 . \mathrm{V}$ and $5 . \mathrm{VI}$, in rabelloi present, respectively, 4.7, 6.12, 5.11 and 3.7 branches. In albinensis these same setae have, respectively $3.4,7.8,6.7$ and 2.3 branches. Besides this, in the dorsomentum of rabelloi there are 6 lateral teeth, while in albinensis there are only 4 (Foote, 1954).

The name of this species is dedicated to Dr. Ernesto $\mathrm{X}$. Rabello, a great worker on the entomological research conducted by the Laboratory of Entomology of the School of Public Health, University of S.Paulo.

ACKNOWLEDGEMENT. - To Mr. Daniel Marucci, of the Laboratory of Entomology of the School of Public Health, University of S.Paulo, for the scanning microscope and other pictures photographs in this paper.

FORATTINI, O.P. \& SALLUM, M.A.M. Estudos sobre algumas espécies de Culex (Melanoconion), com a descrição de uma nova, da região meriđional do Brasil. Rev.Saúde públ., S. Paulo, 21 : 123-56, 1987.

RESUMO: Redescreve-se a espécie Culex (Melanoconion) oedipus Root e Cx. (Mel.) plectoporpe Root, bem como descreve-se outra nova, denominada $C x$. (Mel.) rabelloi. O material de estudo foi coletado no Estado de São Paulo, Brasil. As descrições incluem as formas adultas, pupais e larvais, e são acompanhadas de ilustrações representativas desses estágios, além de aspectos de criadouros naturais. Apresentam-se também alguns dados sobre a distribuição geográfica, conhecida até agora, e de comportamento dessas espécies. Assinala-se que as evidências indicam apreciável adaptabilidade desses três culicídeos ao ambiente artificial humano.

UNITERMOS: Culex (Melanoconion) oedipus. Culex (Melanoconion) plectoporpe. Culex (Melanoconion) rabelloi. Culex (Melanoconion) phlogistus. Culex (Melanoconion) albinensis. Insetos vetores. Ecologia de vetores.

\section{REFERENCES}

CLASTRIER, J. Quatre nouveaux Melanoconion (Diptera, Culicidae) de la Guyane Française. Ann. Parosit., Paris, $45: 463-76,1970$.

DARSIE Jr., R.F. Mosquitoes of Argentina. Part I. Keys for identification of adult females and fourth stage larvae in English and Spanish (Diptera, Culicidae). Mosquito System., 17: 153-253, 1985.

DURET, J.P. Las especies argentinas de Culex (Melanoconion) (Diptera-Culicidae). Rev. Soc. Entomol. Argent., 16:67-76, 1953.

DURET, J.P. Las especies argentinas de Culex (Melanoconion) (Diptera-Culicidae). Rev. Soc. Entomol. Argent., $16: 99-121,1954$.
DURET, J.P. Contribucion al conocimiento de los Culex del Paraguay (Diptera-Culicidae). Rev. Soc. Entomol. Argent., 31 : 3-13, 1969.

DYAR, H.G. The mosquitoes of the Americas. Washington, D.C., Washington Carnegie Inst., 1928. (Publ. 387).

FAURAN, P. Notes sur les moustiques de la Guyane. Arch. Inst. Pasteur Guyane Inini, 22(464): 1-15, 1961.

FOOTE, R.H. The larvae and pupae of the mosquitoes belonging to the Culex subgenera Melanoconion and Mochlostyrax. Washington, D.C., US. Department of Agriculture, 1954. (Techn. Bull., 1091). 
FORATTINI, O.P. \& SALLUM, M.A.M. Studies on some species of Culex (Melanoconion), with the description of a new one from Southern Brazil (Diptera: Culicidae). Rev. Saüde públ., S. Paulo, 21 : 123-56, 1987.

GARCIA, M. \& CASAL, O.H. Descripcion de tres pupas : de mosquitos neotropicales (Diptera, Culicidae). Rev. Soc. Entomol. Argent., $27: 5-10,1965$.

HARBACH, R.E. \& KNIGHT, K.L. Taxonomists-glossary of mosquito anatomy. Marlton, NJ, Plexus Publishing Inc., 1980.

HARBACH, R.E. et al. A new species of Culex (Melanoconion) from Southern America (Diptera, Culicidae). Mosquito System., 16:185-200, 1984.

HEINEMANN, S.J. \& BELKIN, J.N. Collection records of the Project "Mosquitoes of Middle America". 13 - South America: Brazil (BRA, BRAP, BRB), Ecuador (ECU), PERU (PER), Chile (CH). Mosquito System., 11 . $61-118,1979$.

KNIGHT, K.L. \& STONE, A. A catalog of the mosquitoes of the world. 2nd ed. College Park, Md, Entomological Society of America, 1977.

KOMP, W.H.W. Notes on the validity of the types of the species in the subgenera Mochlostyrax and Melanoconion in the U.S. National Museum (Diptera, Culicidae). Proc. ent. Soc. Washington, 37:1-11, 1935.

LANE, J. Neotropical Culicidae. São Paulo, University of São Paulo, 1953. v. 1.

MITCHELL, C.J. \& DARSIE Jr., R.F. Mosquitoes of Argentina. Part II - Geographic distribution and bibliography (Diptera, Culicidae). Mosquito System., 17: 279-360, 1985 .

OLIVEIRA, R.L. de Alguns aspectos da ecologia dos mosquitos (Diptera: Culicidae) de uma área de planície (Granjas Calabria), em Jacarepaguá, Rio de Janeiro. I - Frequêência comparativa das espécies em diferentes ambientes e métodos de coleta. Mem. Inst. Oswaldo Cruz., Rio de Janeiro, 79:479-90, 1984.
ROOT, F.M. Studies on Brazilian mosquitoes. III - The genus Culex. Amer.J. Hyg., 7:574-98, 1927.

ROZEBOOM, L.E. \& KOMP, W.H.W. A review of the species of Culex of the subgenus Melanoconion. (Diptera, Culicidae). Ann. ent. Soc. Amer., 43: 75-114, 1950.

SENEVET, G. \& ABONNENC, E. Les moustiques de la Guyane Française. II - Le genre Culex. Arch. Inst. Pasteur Algérie, 17: 62-134, 1939.

SIRIVANAKARN, $S$. The female cibarial armature of New World Culex, subgenus Melanoconion and related subgenera with notes on this character in subgenera Culex, Lutzia and Neoculex and genera Galindomyia and Deinocerites (Diptera: Culicidae). Mosquito System., $10: 474 \cdot 92,1978$.

SIRIVANAKARN, S. \& JAKOB, W.L. Notes on the distribution of Culex (Melenoconion) mosquitoes in Northeastern Argentina (Diptera: Culicidae). Mosquito System., 13: $195-9,1981$.

SIRIVANAKARN, S. A review of the systematics and a proposed scheme of internal classification of the New World subgenus Melanoconion of Culex (Diptera, Culicidae). Mosquito System., $14: 265-333,1982$.

Received for publication: 20/11/1986. Accepted for publication: 12/02/1987. 


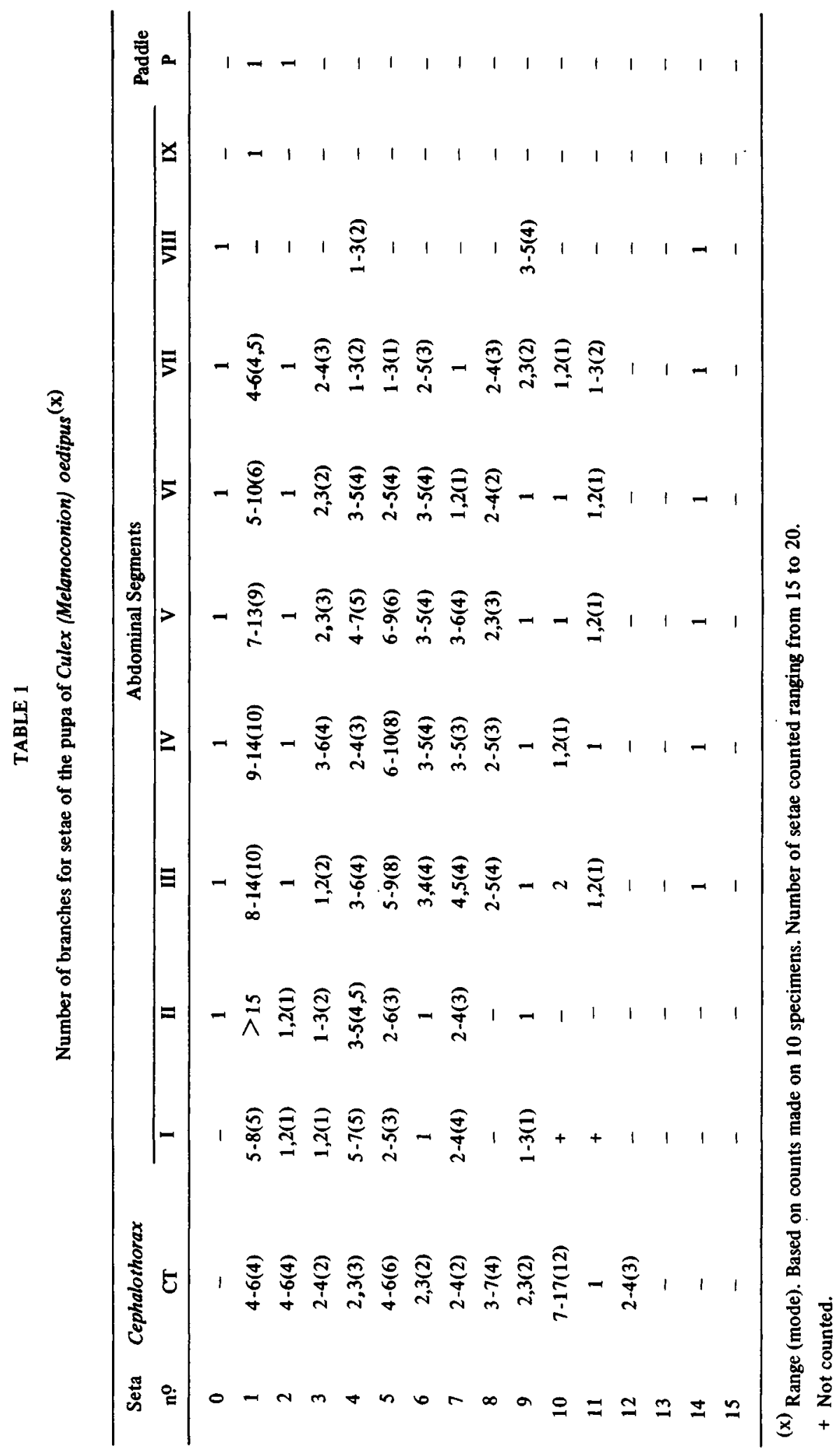




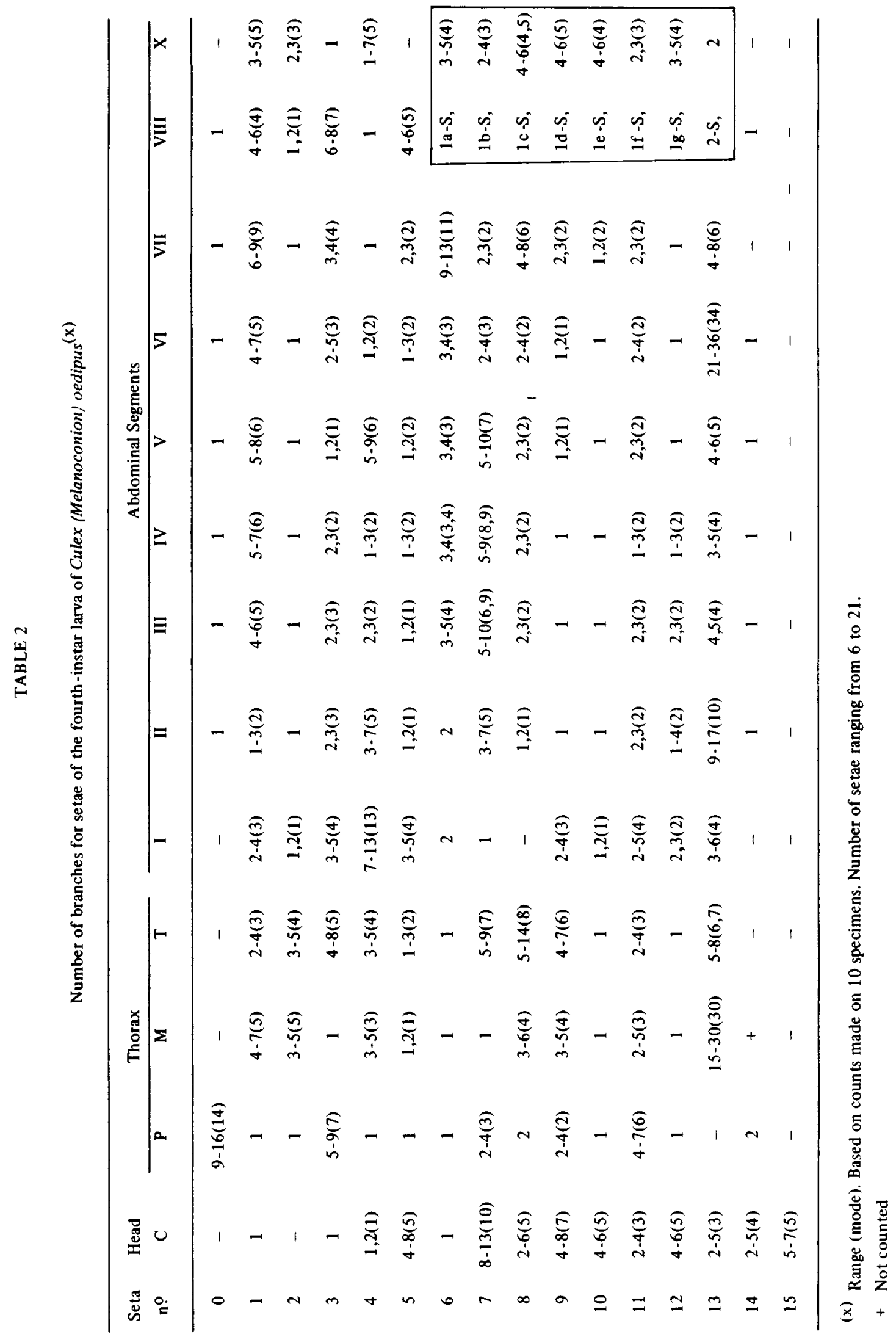




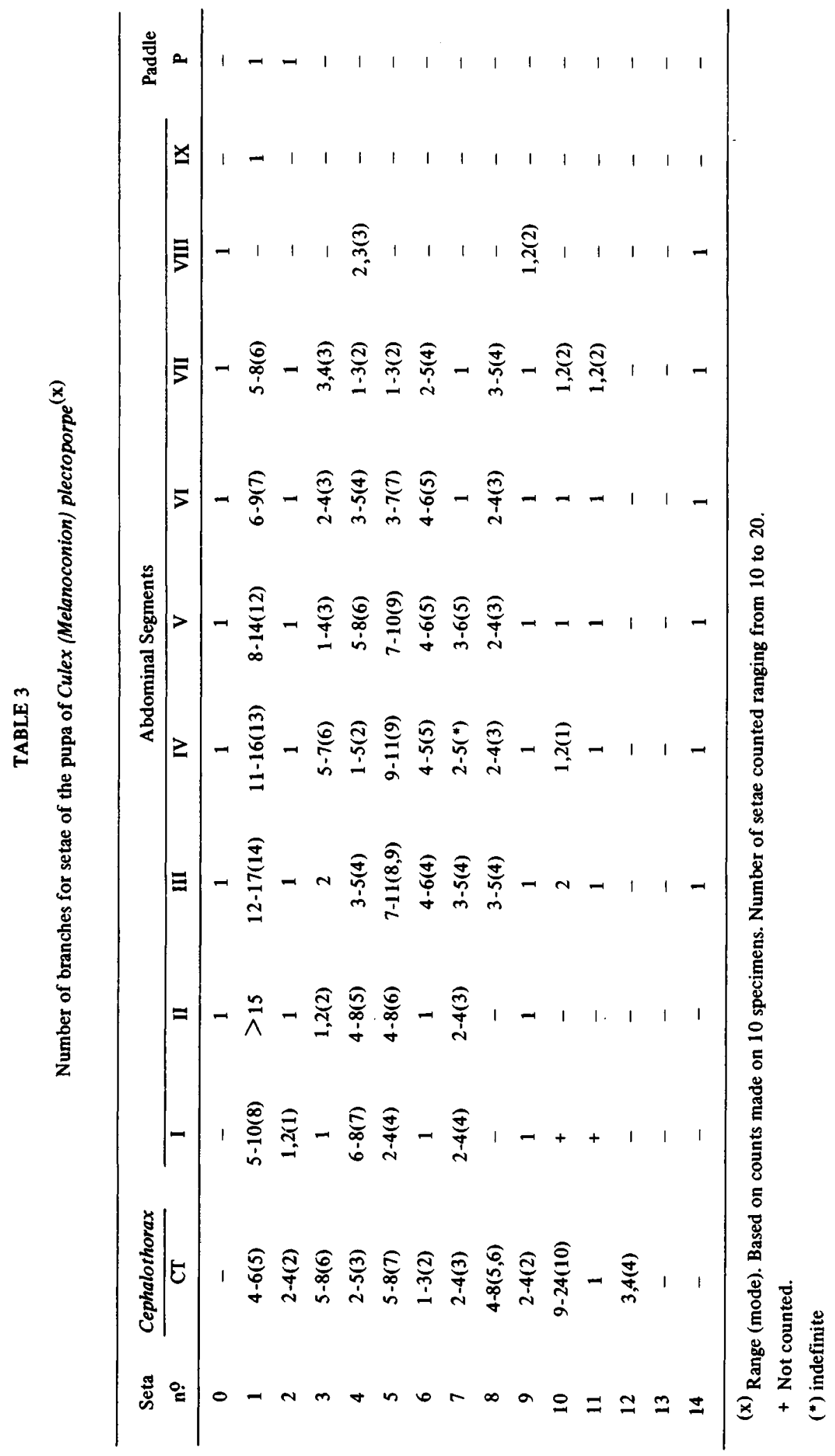



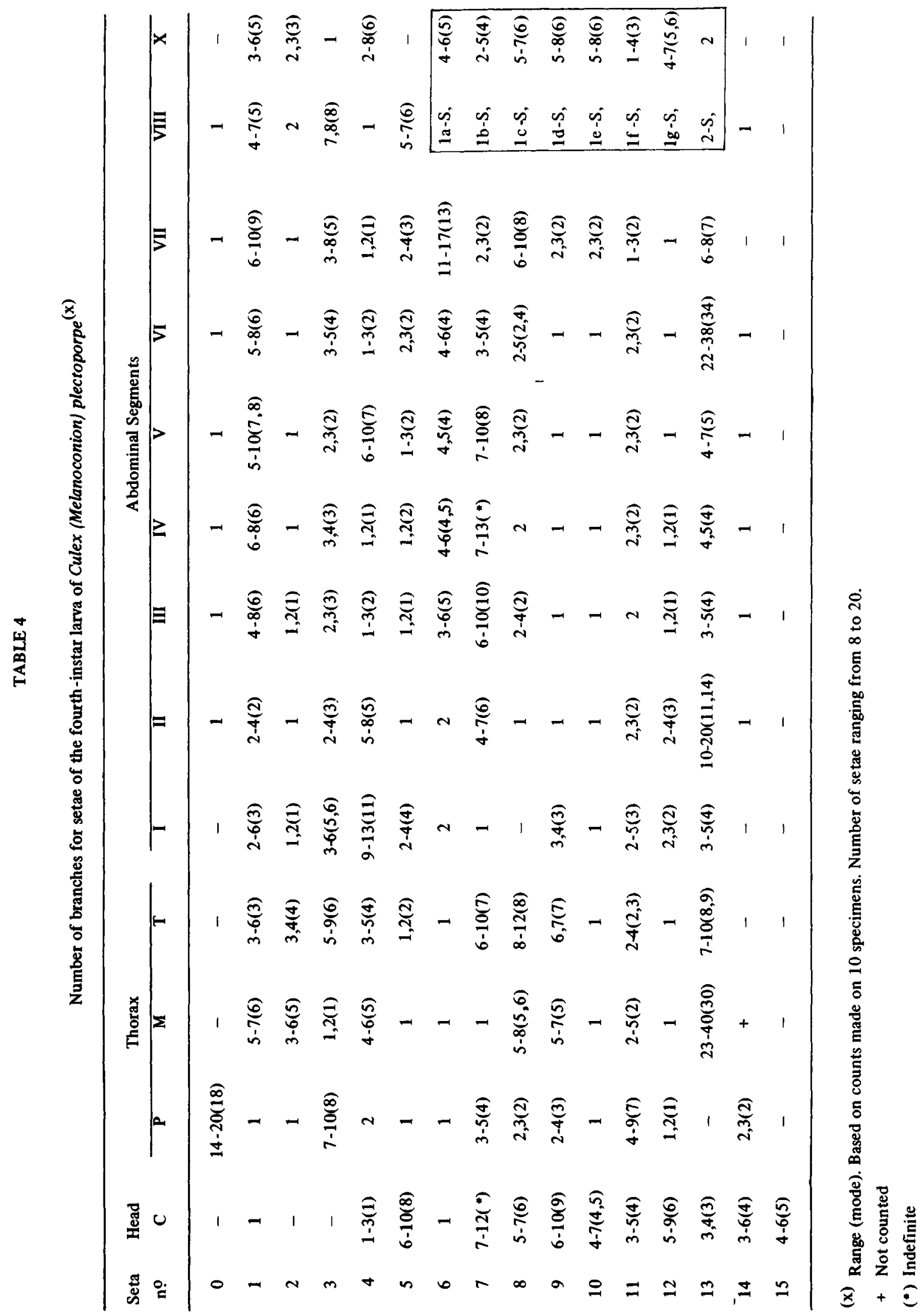


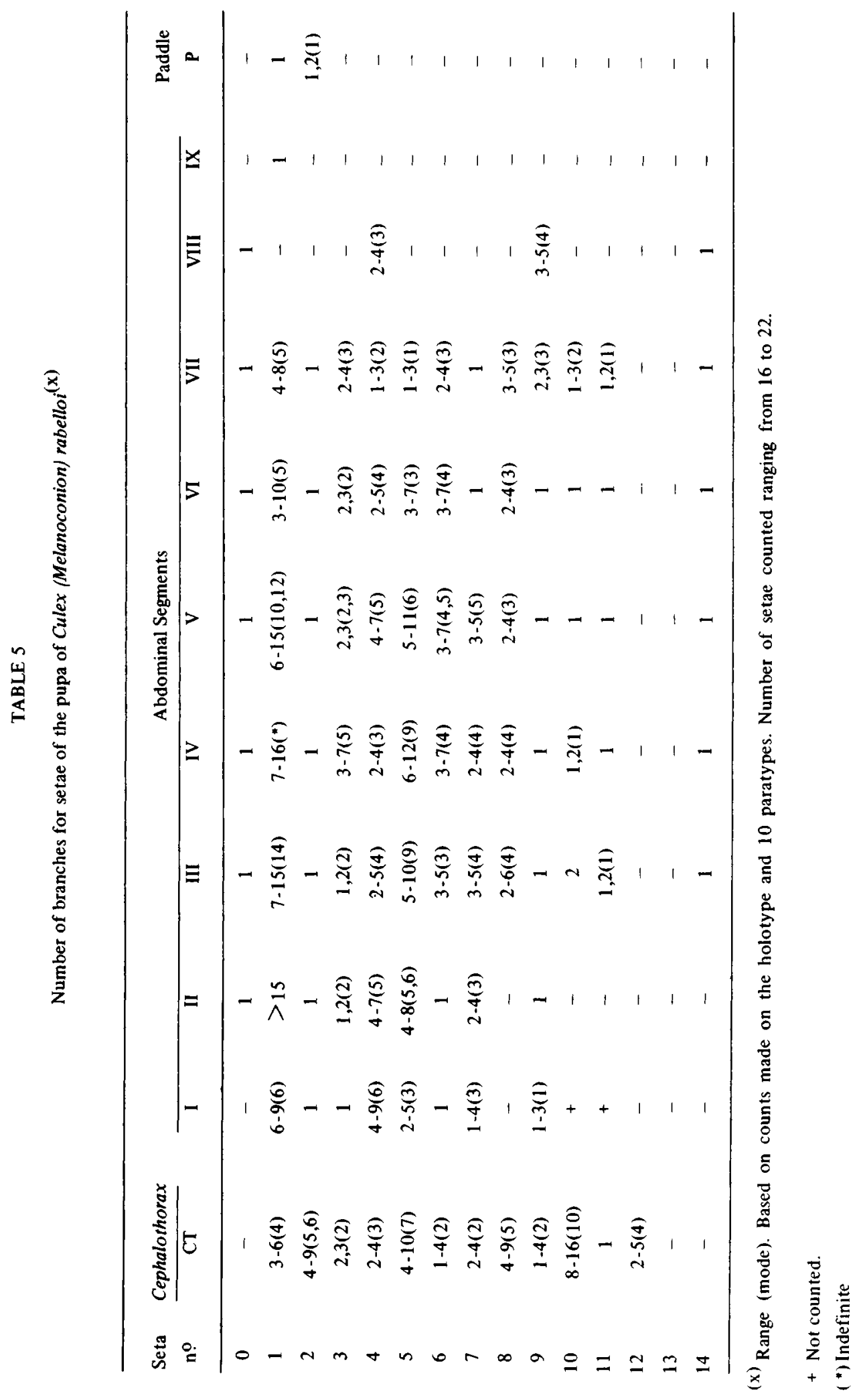




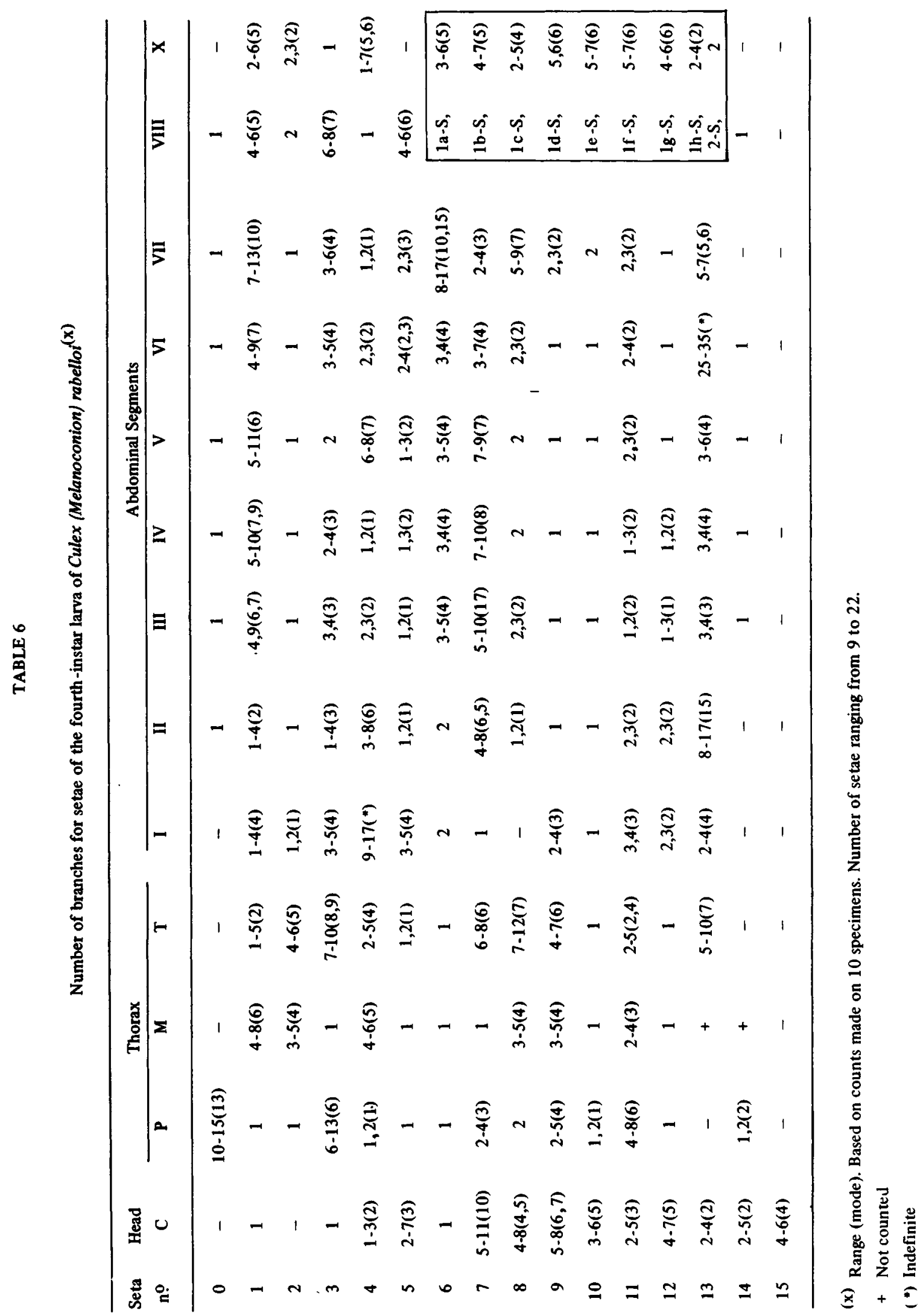


FORATTINI, O.P. \& SALLUM, M.A.M. Studies on some species of Culex (Melanoconion), with the description of a new one from Southern Brazil (Diptera: Culicidae). Rev. Saúde públ., S. Paulo, 21 :123-56, 1987.

\section{Culex (Melanoconion), collection places. I}
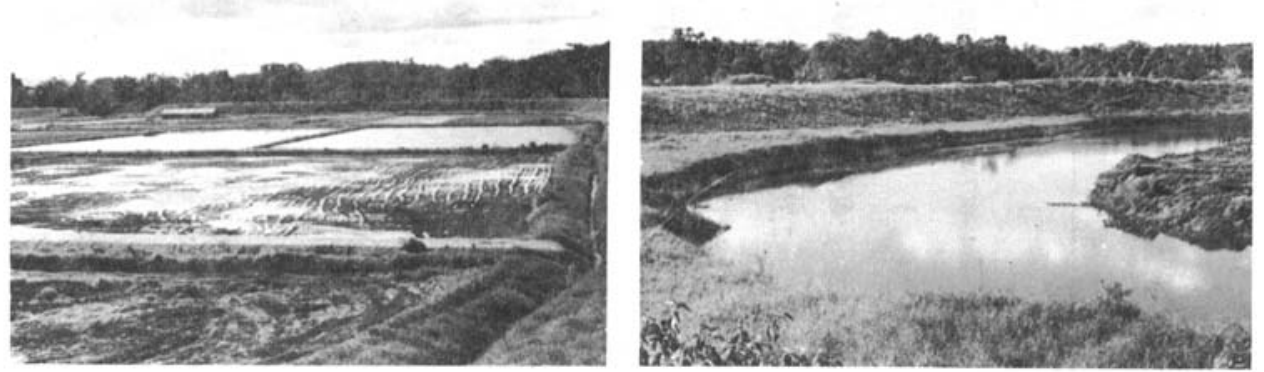

C
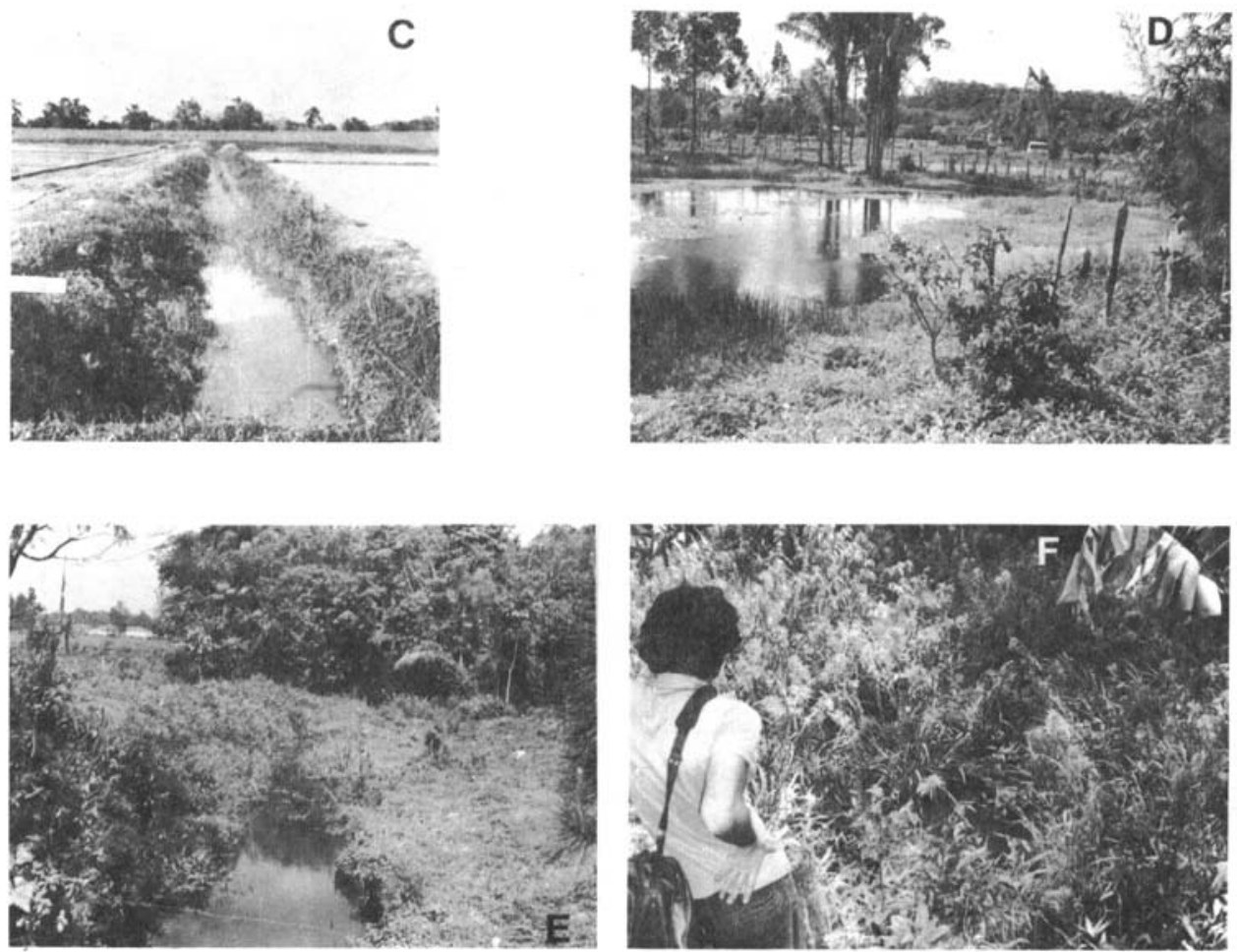

Fig. 1 - Environmental views and aspects of Ribeira Valley, Pariquera-Açú County, São Paulo State, Brazil. A - View of the Experimental Station; B - artificial pond at the Experimental Station $(C x$. oedipus and $C x$. rabelloi); $C$-ditch at the Experimental Station (Cx. oedipus and $C x$. plec. toporpe); D - pond in the Pariquera-Mirim locality (Cx. oedipus, CX. plectoporpe and $C x$. ra. belloi); E - streamlet near secondary wood in the Pariquera-Mirim locality ( $C x$. oedipus and Cx. rabelloi); $\mathrm{F}$ - small pool densely covered by molasses grass and near the edge of a primitive forest, in the Pariquera-Mirim locality (Cx. plectoporpe). 
FORATTINI, O.P. \& SALLUM, M.A.M. Studies on some species of Culex (Melanoconion), with the description of a new one from Southern Brazil (Diptera:Culicidae). Rev. Saúde públ., S. Paulo, $21: 123-56,1987$.

\section{Cx.(Mel.) oedipus}
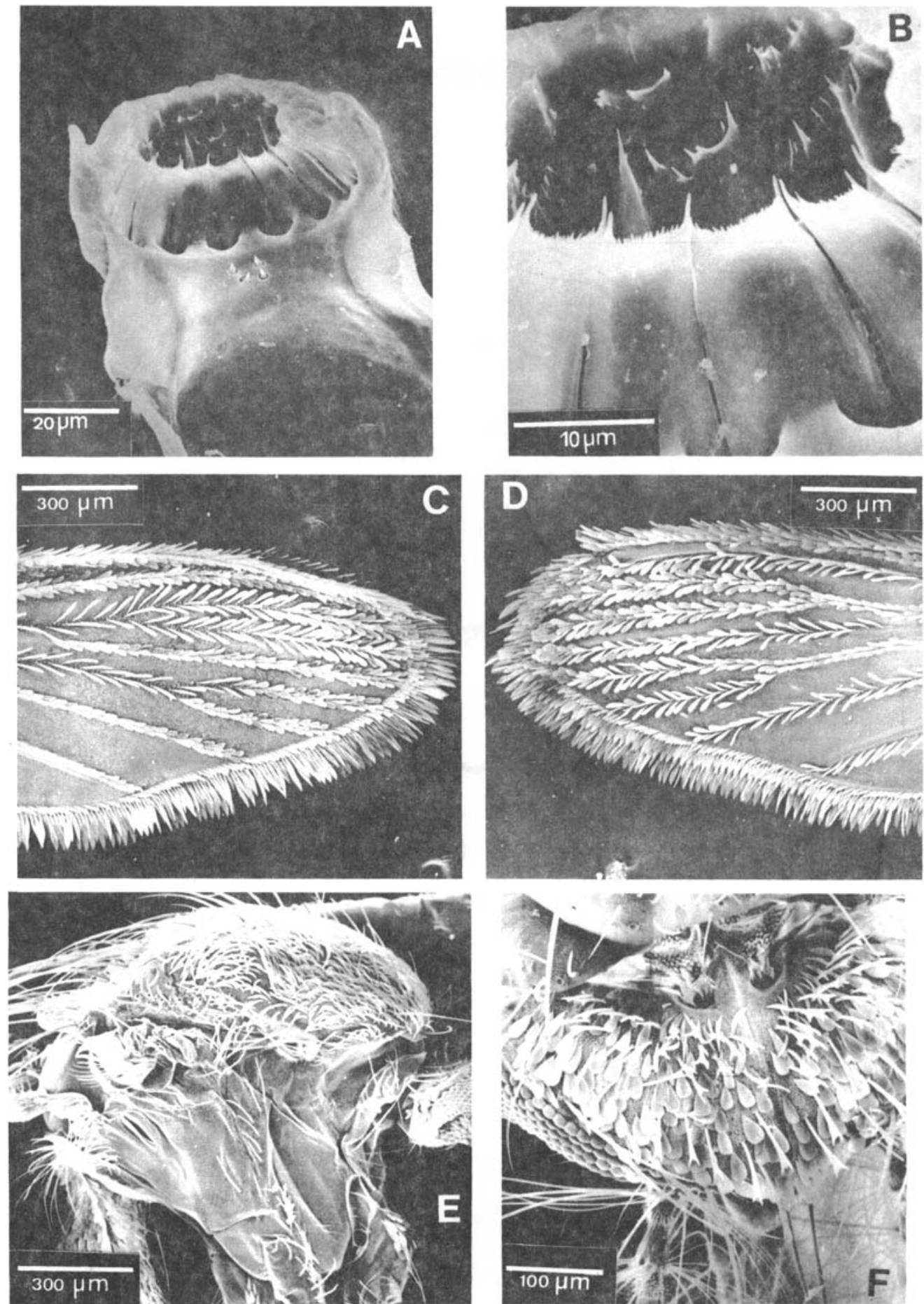

Fig. 2 - Female: A - dorsal aspect of cibarial armature; B - detail of figure A focusing the cibarial teeth; $C$ - dorsal aspect of distal right wing scaling; D - ventral aspect of distal right wing scaling; E - aspect of lateral right side of thorax; Male: F - dorsal aspect of head showing forked and falcate scales. 


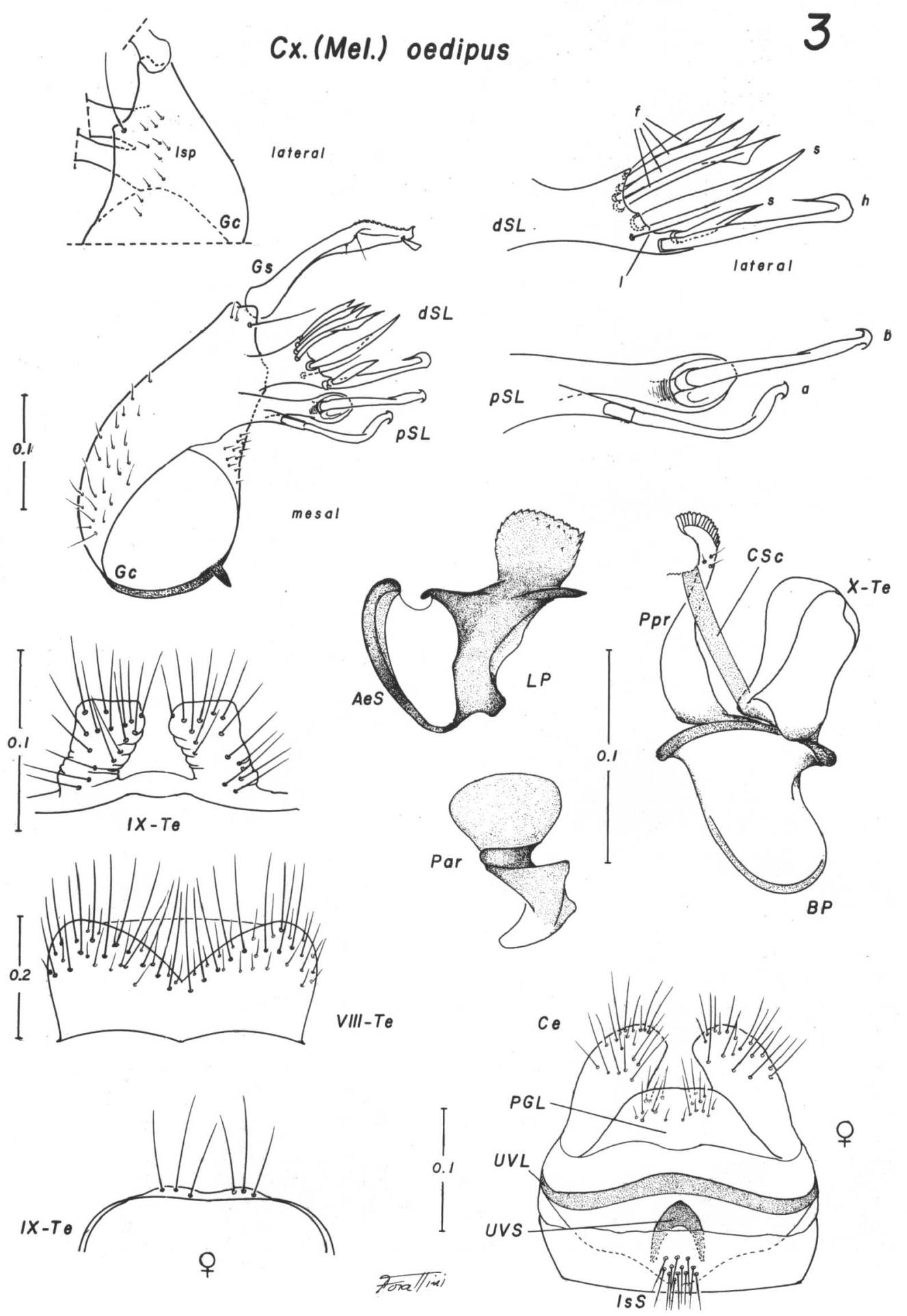

Fig. 3 - See caption page 156. 


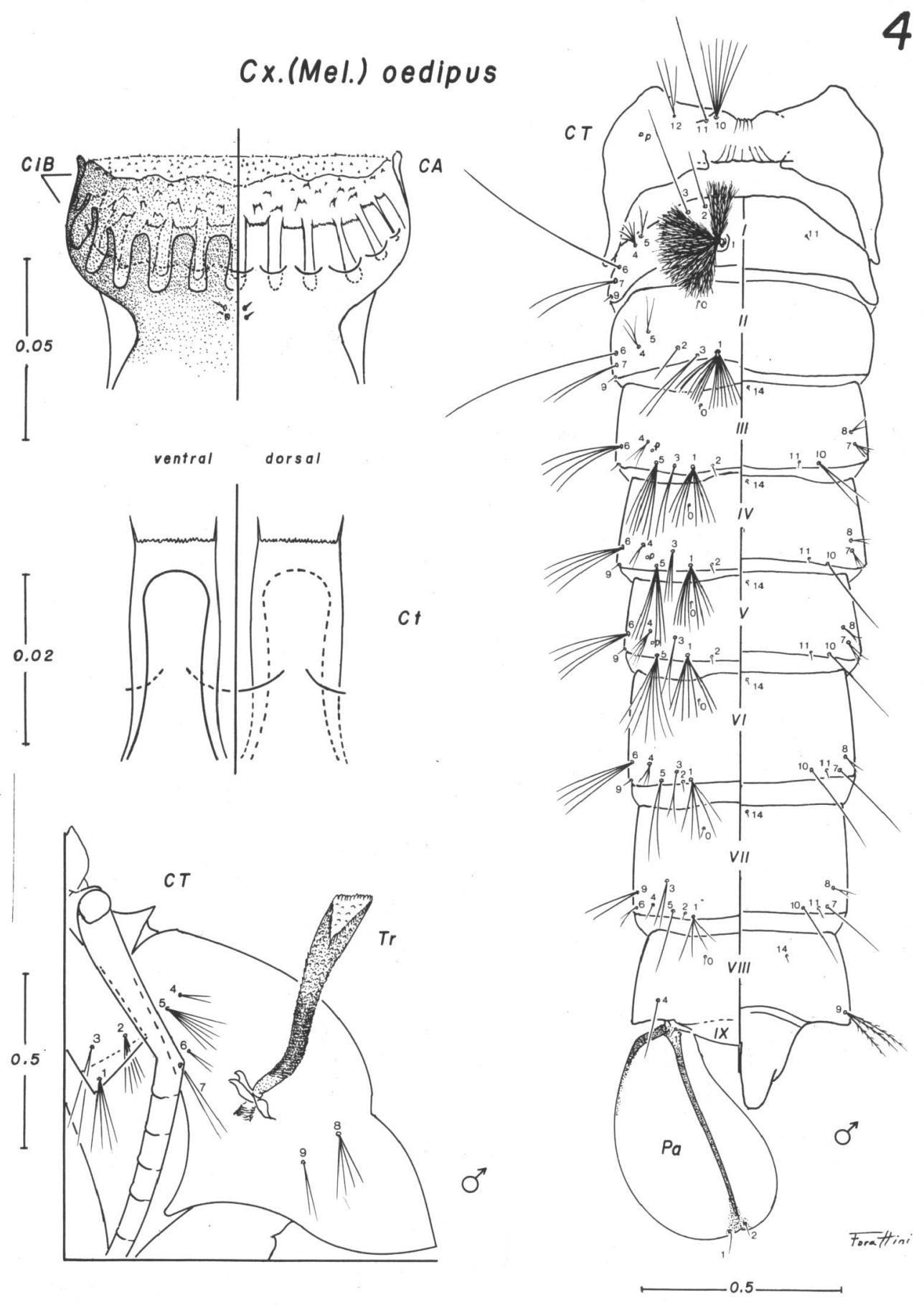

Fig. 4 - See caption page 156. 


\section{Cx.(Mel.) oedipus}

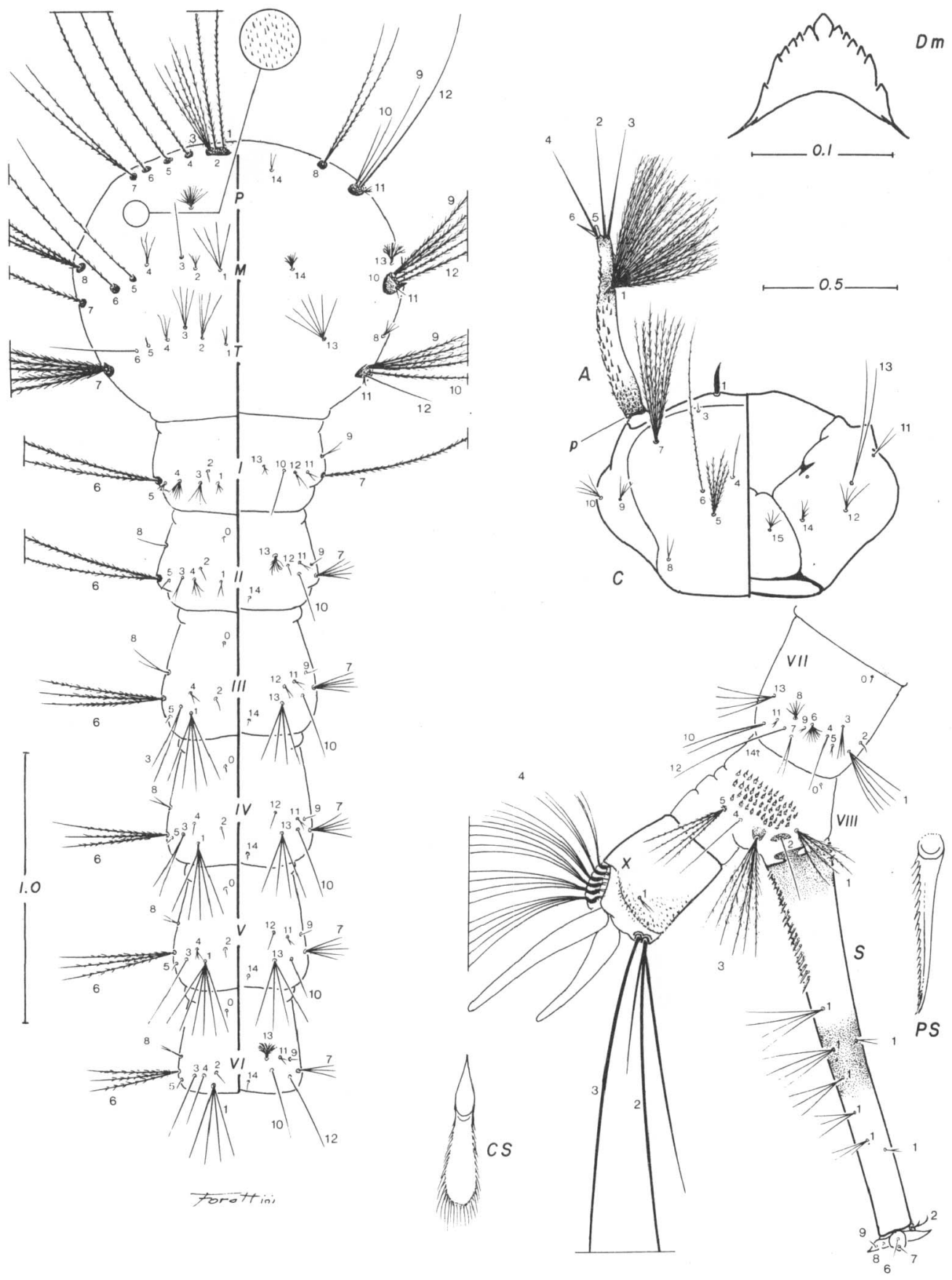

Fig. 5 - See caption page 156. 


\section{Cx.(Mel.) plectoporpe}

\section{6}
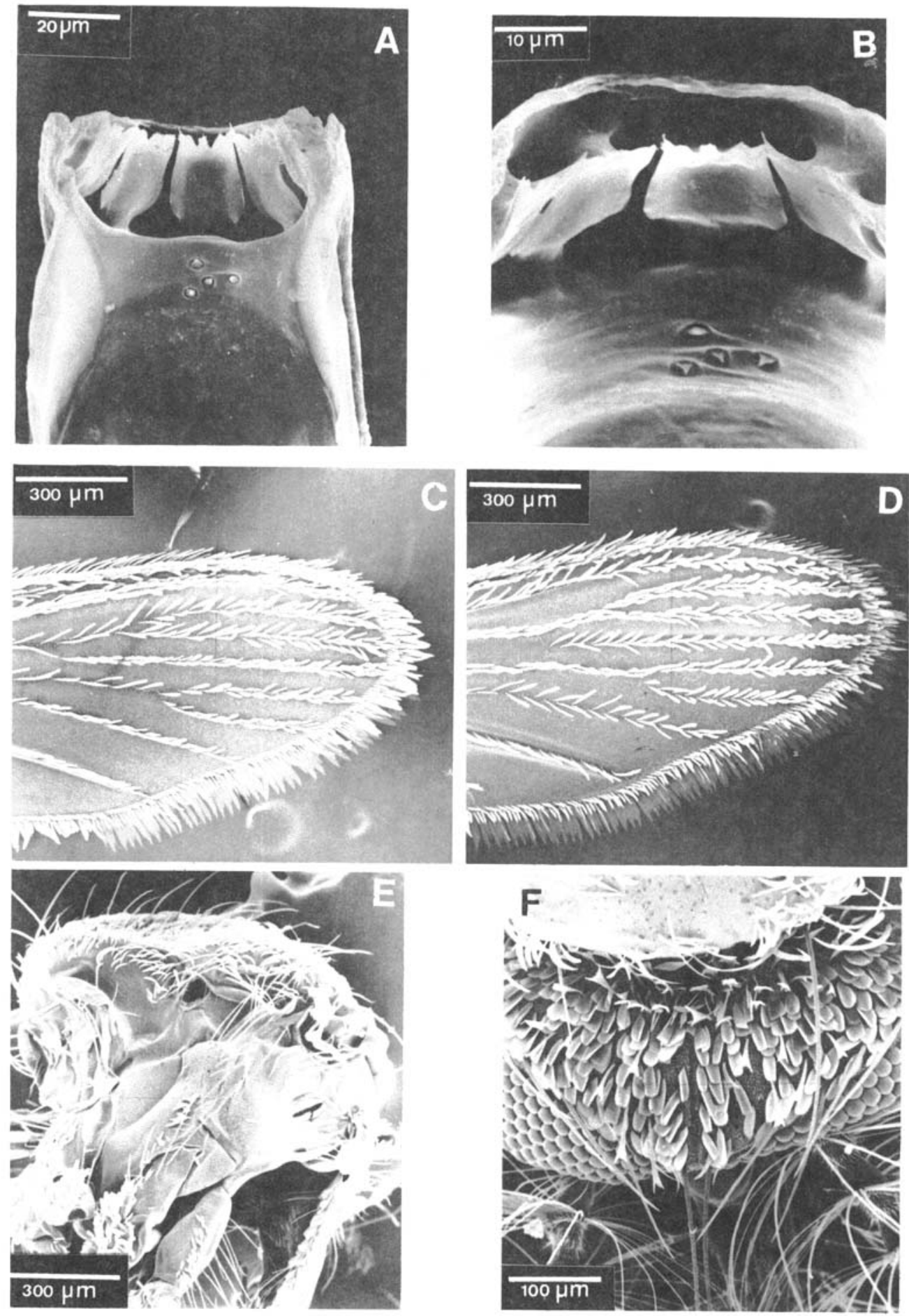

Fig. 6 - Female: A - dorsal aspect of cibarial armature; B - detail of figure A focusing the cibarial teeth; C - dorsal aspect of distal right wing scaling; D - ventral aspect of distal left wing scaling; E - aspect of lateral left side of thorax; Male: F - dorsal aspect of head showing forked and falcate scales. 


\section{Cx.(Mel.) plectoporpe}
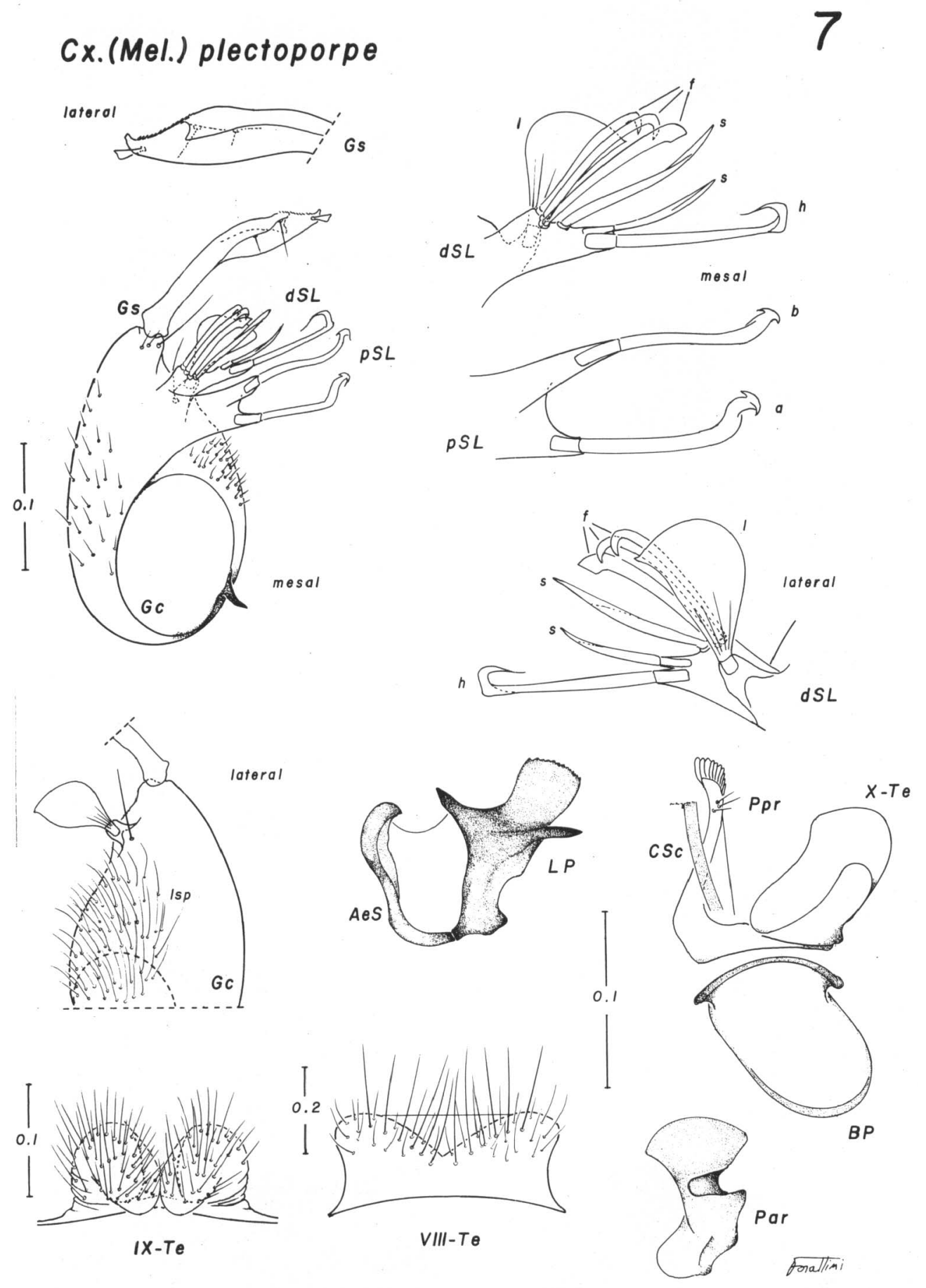

Fig. 7 - See caption page 156. 
CX.(Mel.) phlogistus

8

PARA, BRAZIL
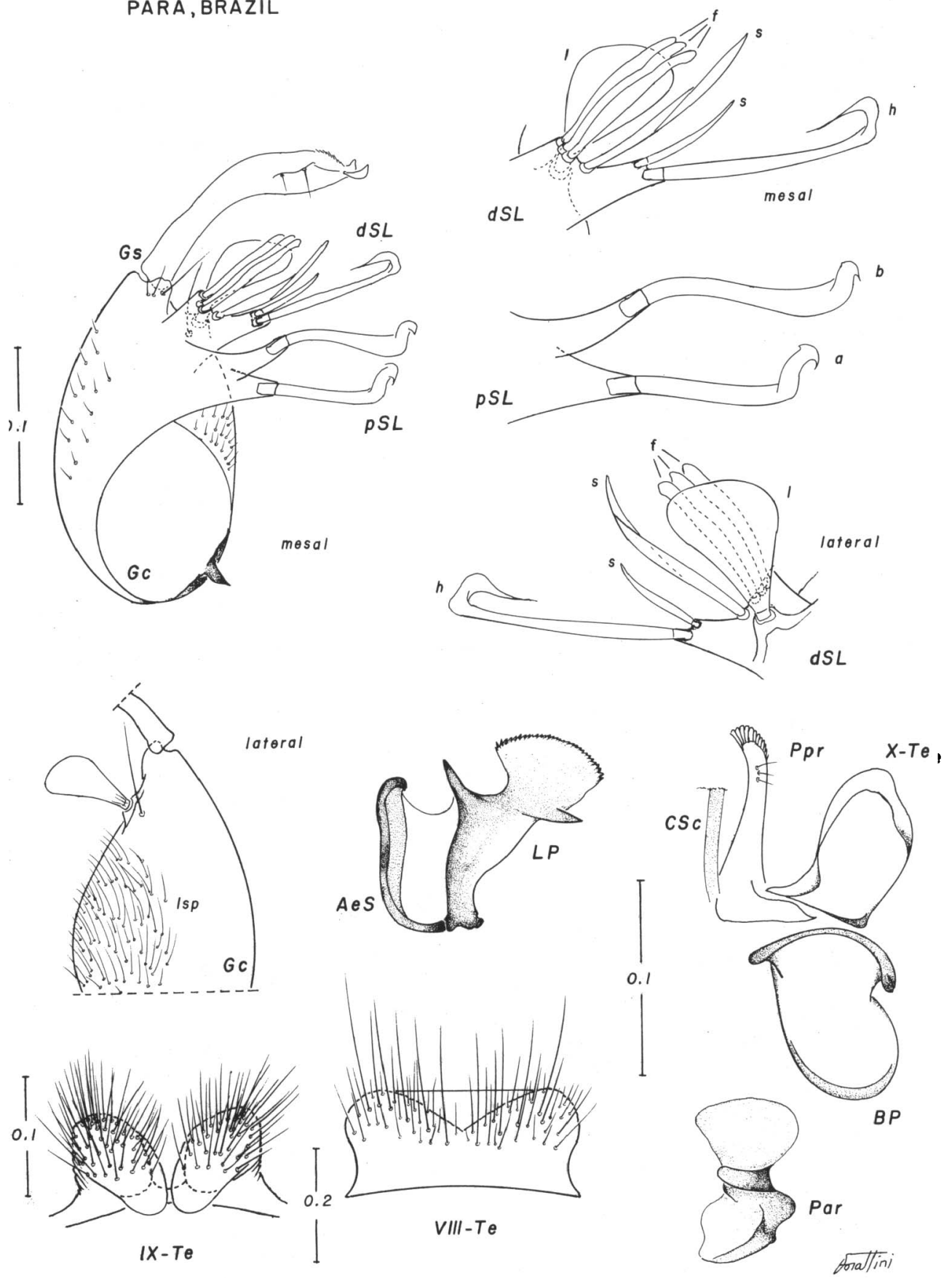

Fig. 8 . See caption page 156. 


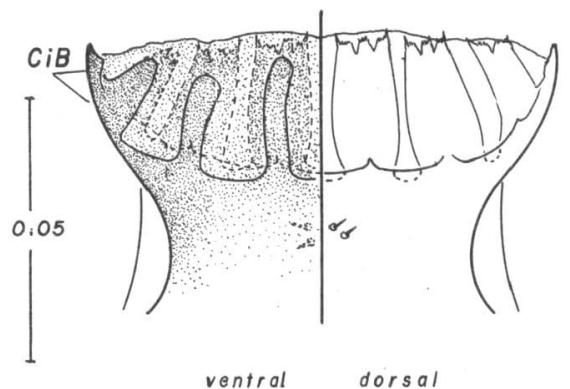

$C A$

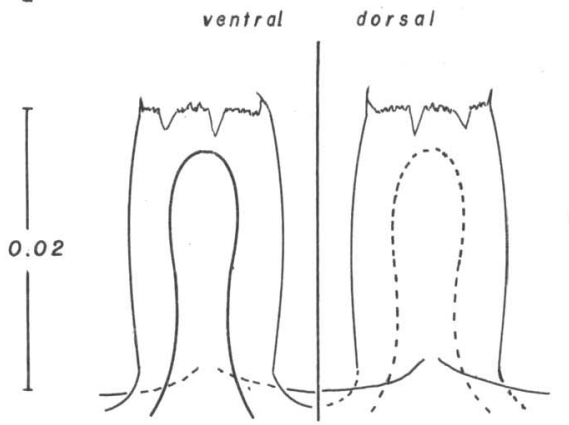

Ct

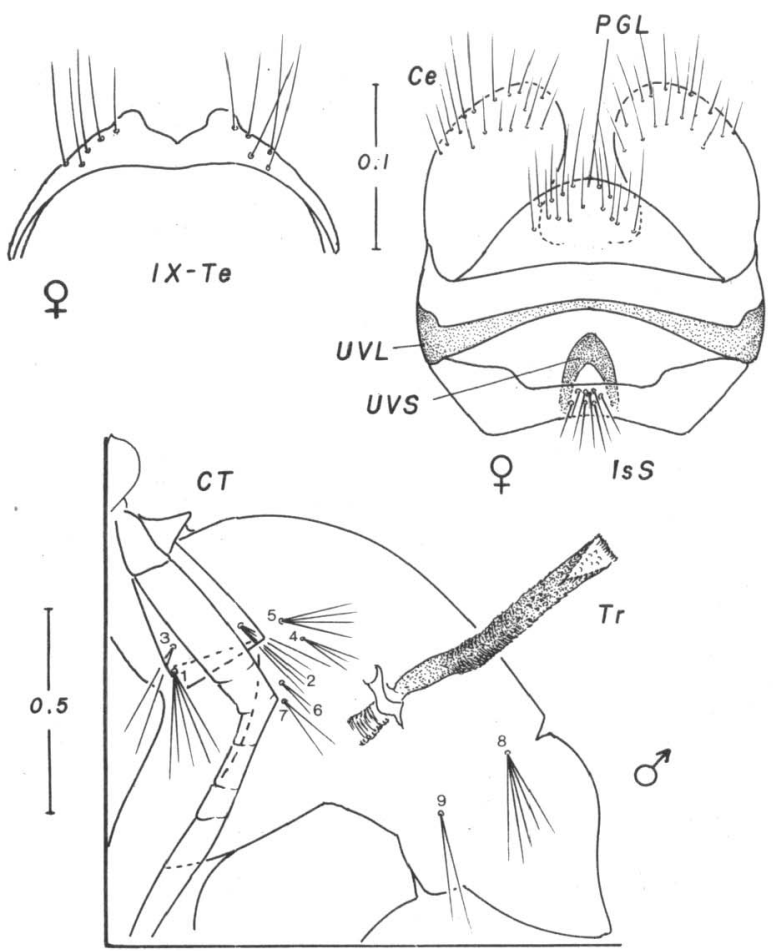

CT
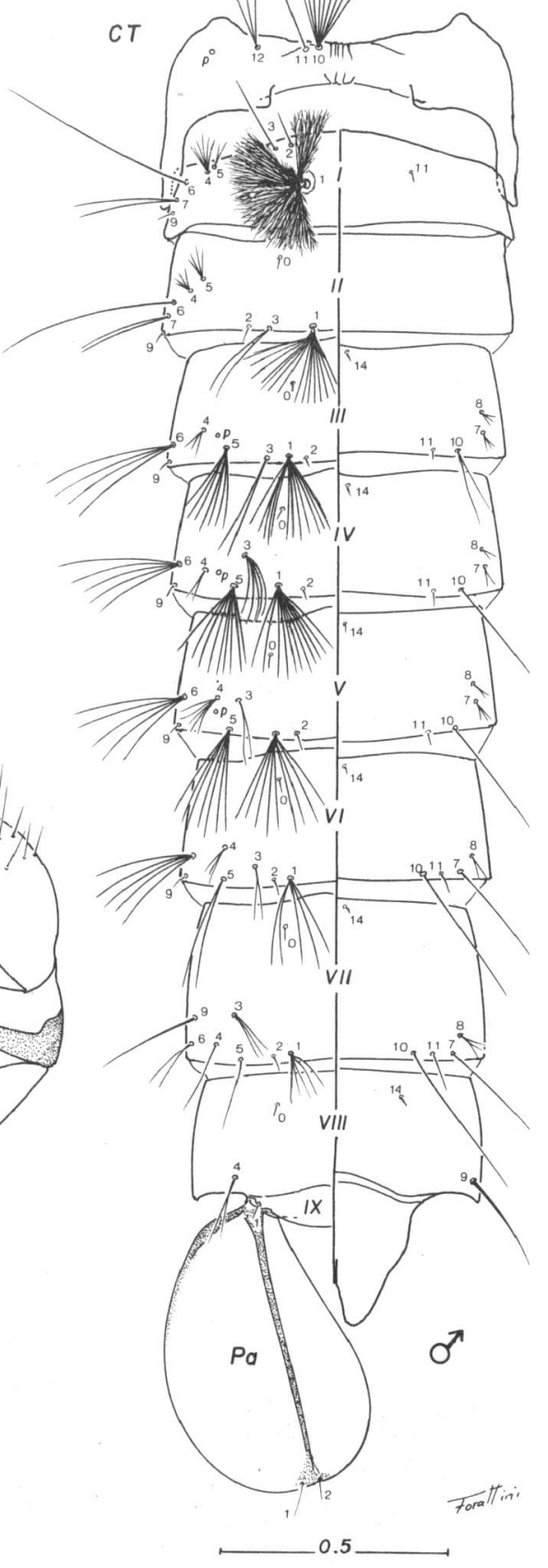

Fig. 9 - See caption page 156. 


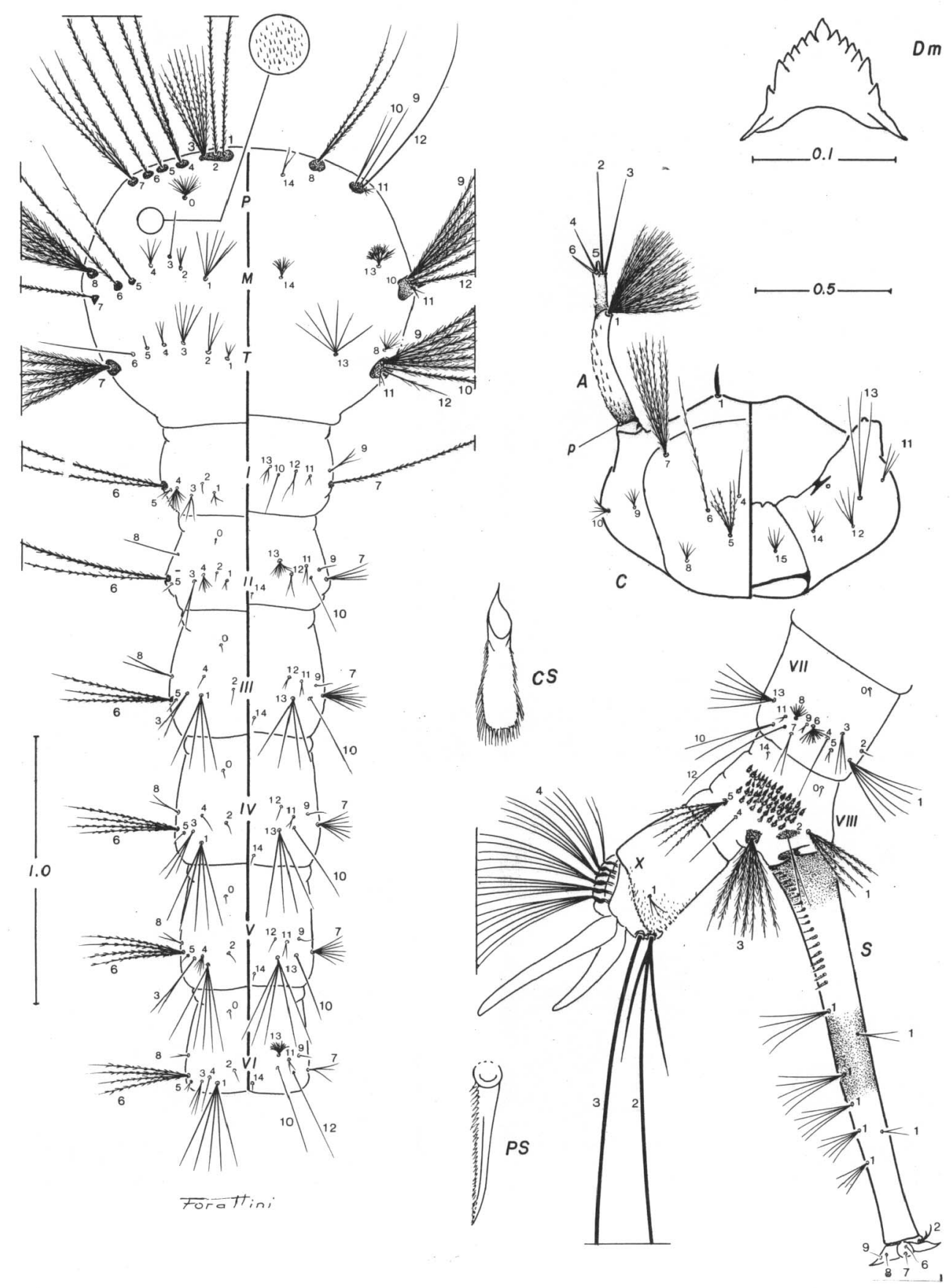

Fig. 10 - See caption page 156. 
FORATTINI, O.P. \& SALLUM, M.A.M. Studies on some species of Culex (Melanoconion), with the description of a new one from Southern Brazil (Diptera: Culicidae). Rev. Saude públ., S. Paulo, 21 : 123-56, 1987.

\section{Cx.(Mel.) rabelloi II}
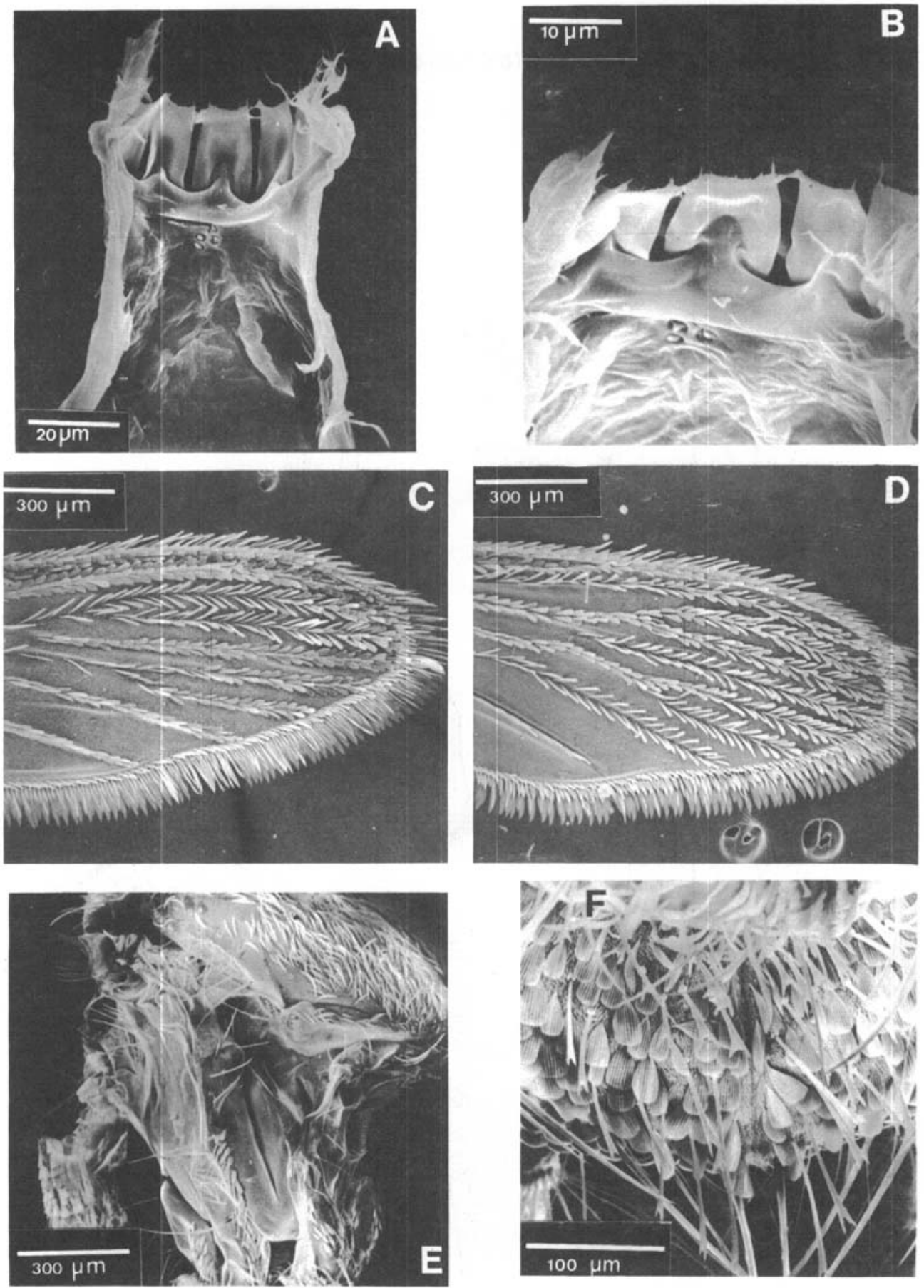

Fig. 11 -Female: A - dorsal aspect of cibarial armature; B - detail of figure A focusing the cibarial teeth; C - dorsal aspect of distal right wing scaling; D - ventral aspect of distal left wing scaling; E - aspect of lateral right side of thorax. Male: F - dorsal aspect of head showing forked and falcate scales. 


\section{CX. (Mel.) rabelloi}

S.PAULO, BRAZIL
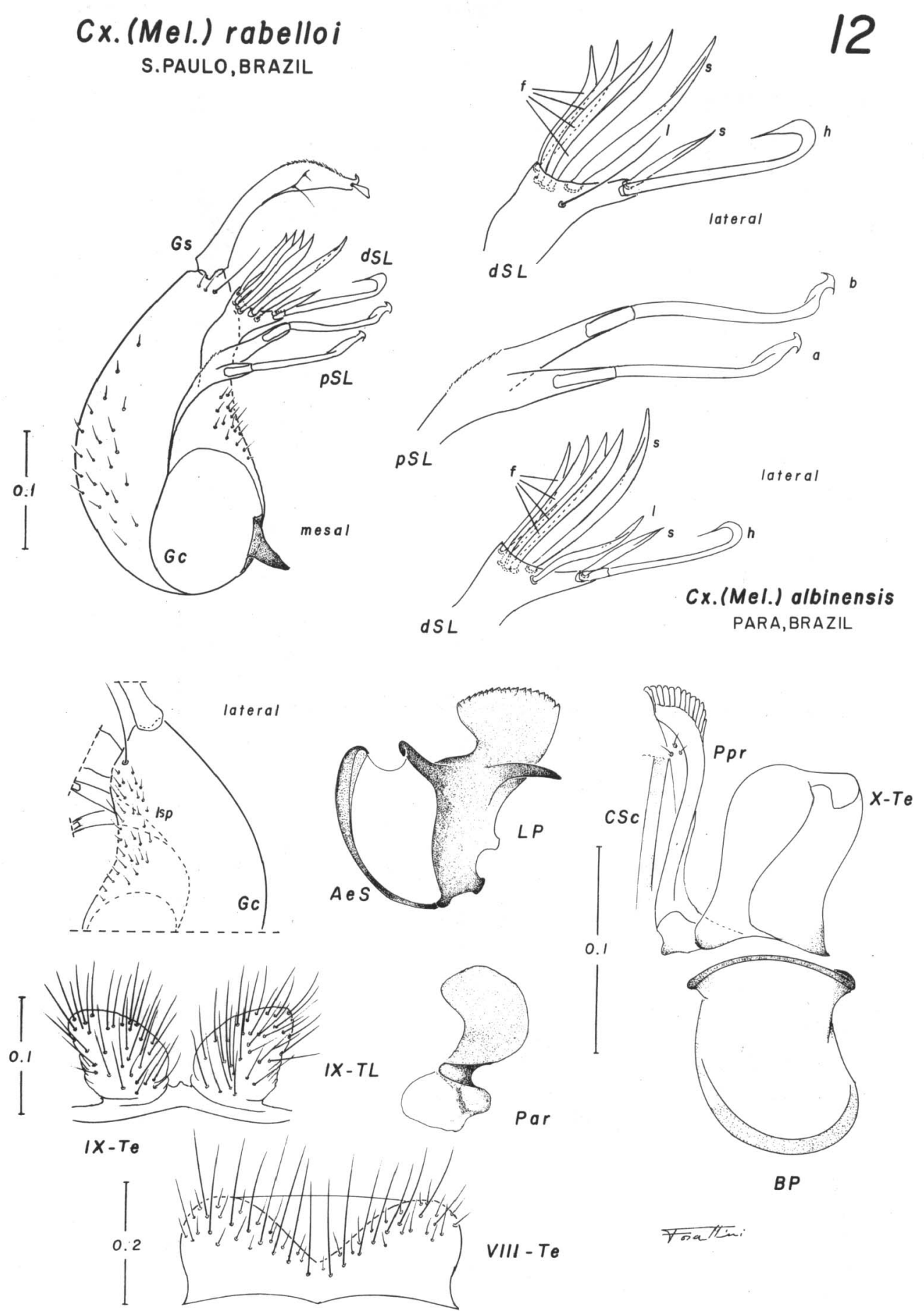

Foattin.

Fig. 12 . See caption page 156. 
Cx. (Mel.) rabelloi

13

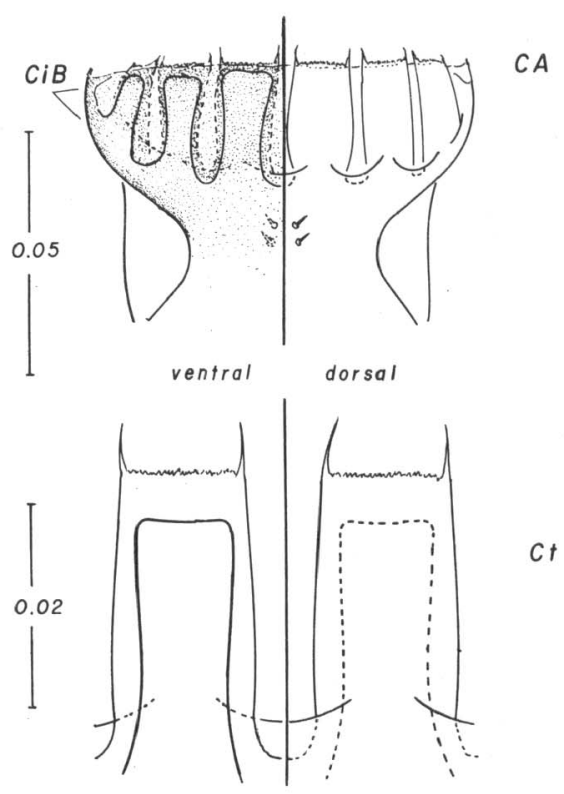

$C A$

$\mathrm{Ct}$
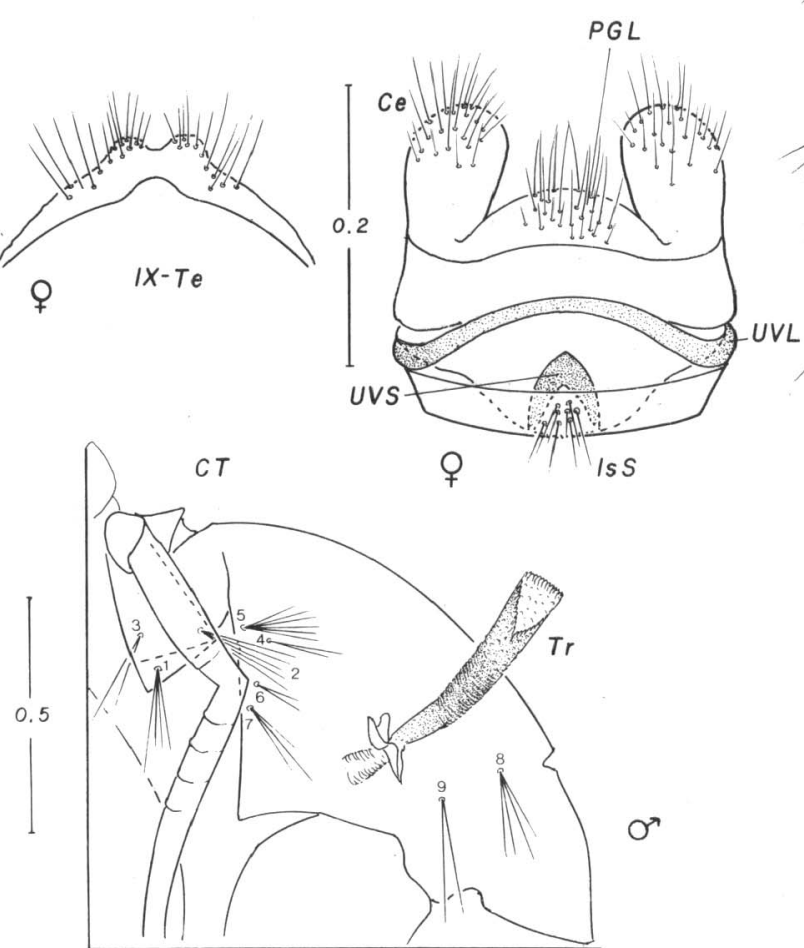

CT
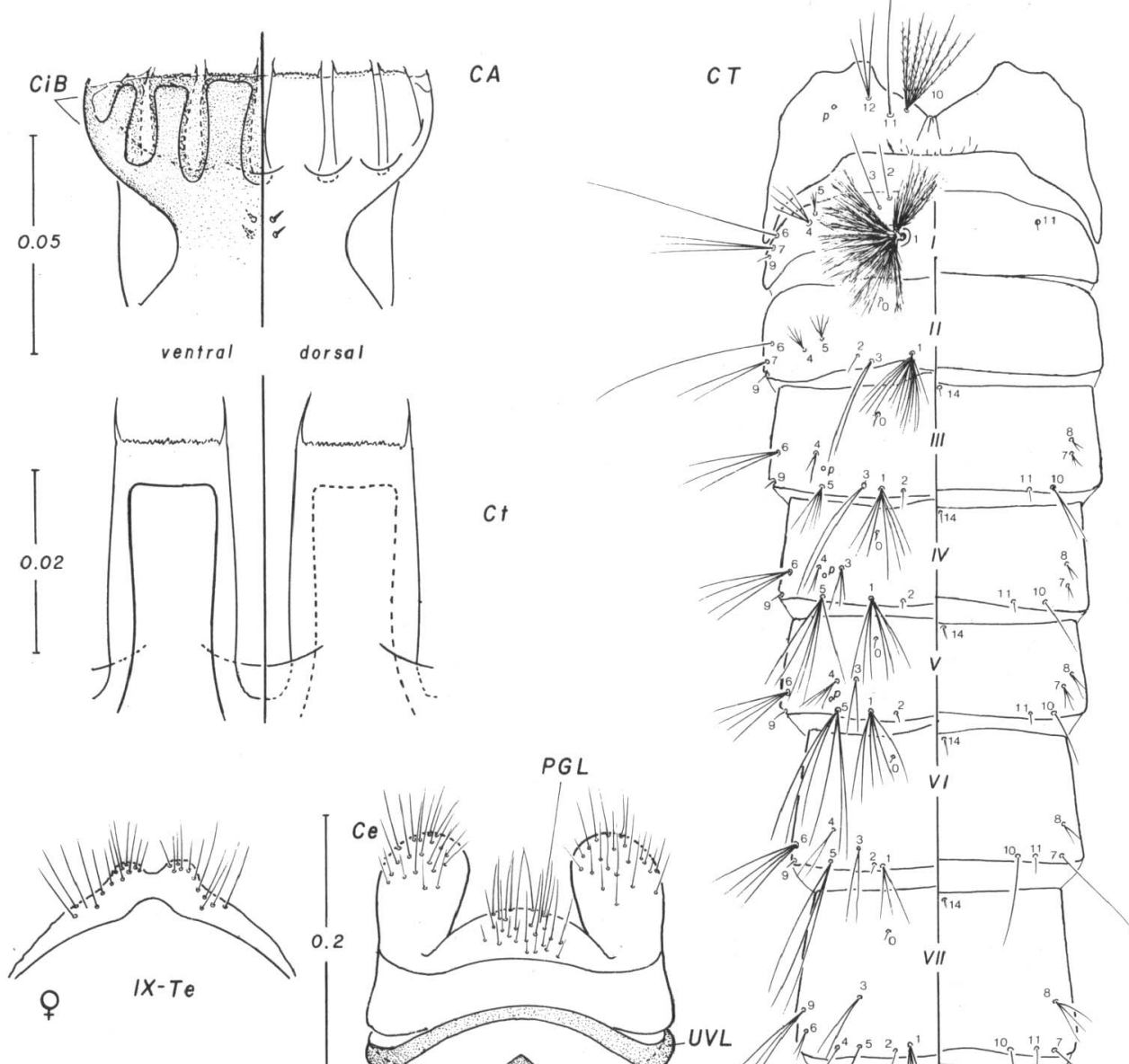


\section{Cx.(Mel.) rabelloi}

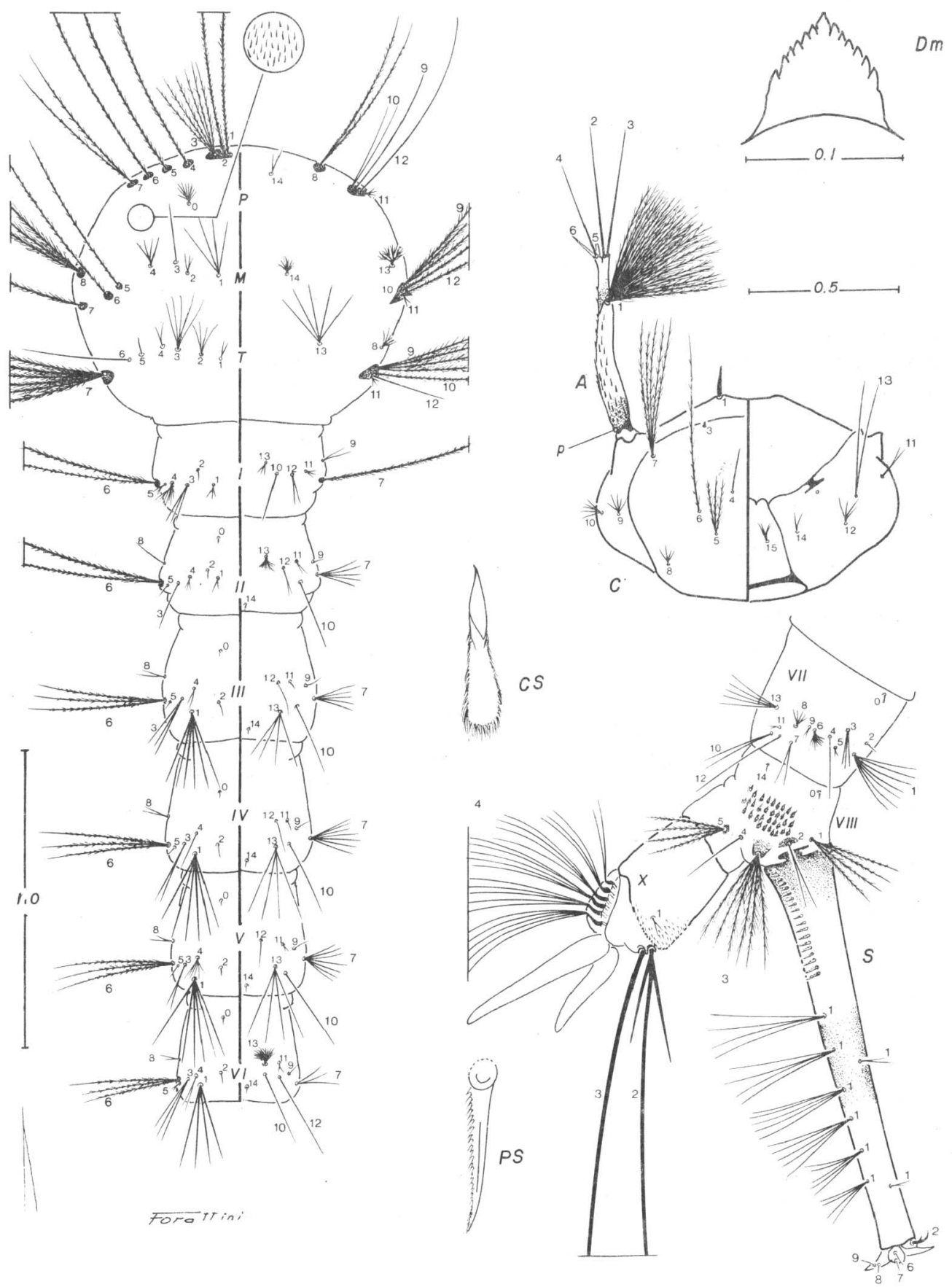

Fig.l 4 . See caption page 156. 
FORATTINI, O.P. \& SALLUM, M.A.M. Studies on some species of Culex (Melanoconion), with the description of a new one from Southern Brazil (Diptera:Culicidae). Rev. Saúde puibl., S. Paulo, 21 : 123-56, 1987.

Figs. $3-5,7 \cdot 10$ and $12 \cdot 14 \cdot$ Abbreviations used:
a - seta $a$ of pSL; seta $a$ of Gs
$A$ - antenna
AeS - aedeagal sclerite
$\mathrm{b}-\operatorname{seta} b$ of $\mathrm{pSL}$; seta $b$ of $\mathrm{Gs}$
BP - basal piece
$c$ - seta $c$ of $\mathrm{Gs}$
$\mathrm{C}$ - cranium
CA - cibarial armature
$\mathrm{Ce}$ - cercus
$\mathrm{CiB}$ - cibarial bar
CS - comb scale
CSc - cercal sclerite
$\mathrm{Ct}$ - cibarial tooth
CT - cephalothorax
Dm - dorsomentum
dSL - distal division of subapical lobe
$f$ - flat seta of dSL (= foliform)
$\mathrm{Gc}$ - gonocoxite
Gs - gonostylus
h - hooked seta of dSL
IsS - insular seta
1 - leaf

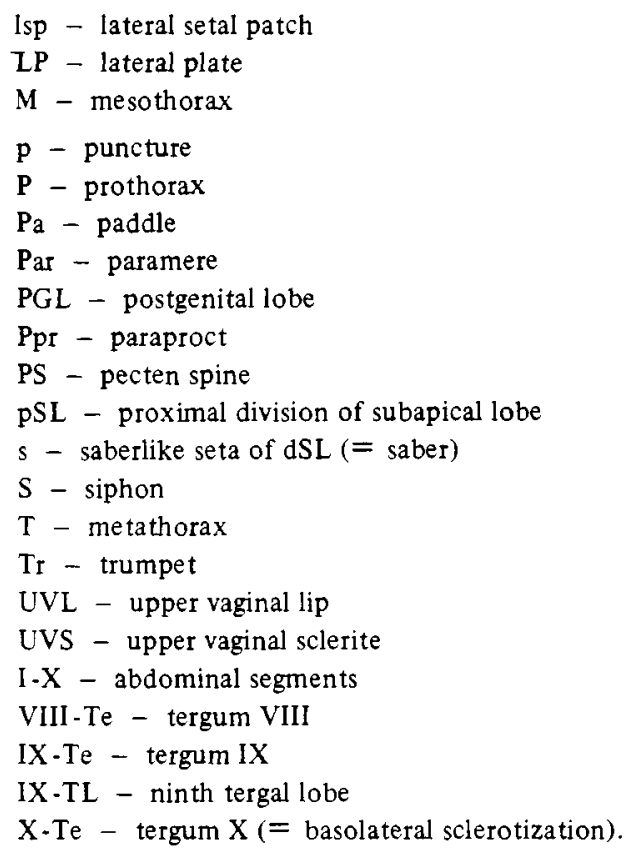

